

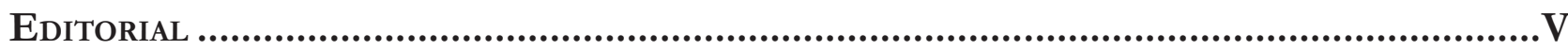

Carlos Ayres Britto, Lilian Rose Lemos Soares Nunes e Marcelo Dias Varella

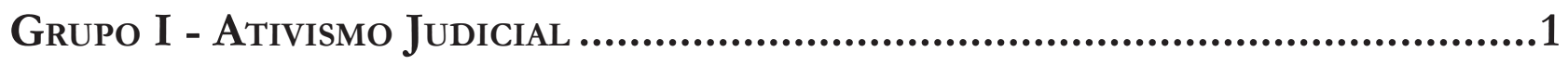

APONTAMENTOS PARA UM DEBATE SOBRE O ATIVISMO JUdiCIAL ................................................ 3 Inocêncio Mártires Coelho

A razão sem voto: o Supremo Tribunal Federal e o governo da maioria......................24 Luís Roberto Barroso

O PROBLEMA DO ATIVISMO JUDICIAL: UMA ANÁLISE DO CASO MS3326 ......................................52 Lenio Luiz Streck, Clarissa Tassinari e Adriano Obach Lepper

Do ativismo Judicial aO ATIVISMO CONSTITUCIONAL No Estado DE DIREITOS FUNDAMENTAIS..... 63 Christine Oliveira Peter

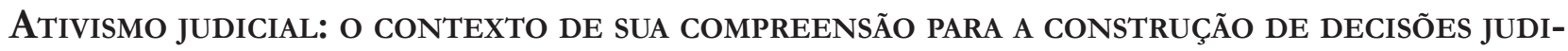
CIAIS RACIONAIS

Ciro di Benatti Galvão

HeRMENÊUTICA FILOSÓFICA E ATIVIDADE JUDICIAL PRAGMÁtICA: APROXIMAÇÕES 101 Humberto Fernandes de Moura

O PAPEL DOS PRECEDENTES PARA O CONTROLE DO ATIVISMO JUDICIAL NO CONTEXTO PÓS-POSITI-

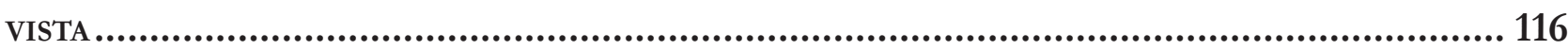
Lara Bonemer Azevedo da Rocha, Claudia Maria Barbosa

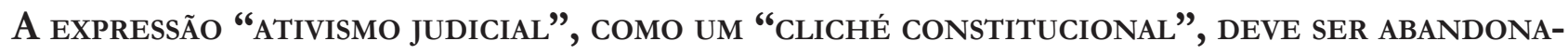
DA: UMA ANÁLISE CRÍTICA 135 Thiago Aguiar Pádua

A atuação do Supremo Tribunal Federal frente aos fenômenos da judicialização da POLÍTICA E DO ATIVISMO JUDICIAL 170

Mariana Oliveira de Sá e Vinícius Silva Bonfim 
Ativismo judicial e democracia: a ATUaÇão do STF E o EXercício da Cidadania no Brasil..191 Marilha Gabriela Reverendo Garau, Juliana Pessoa Mulatinho e Ana Beatriz Oliveira Reis

Grupo II - Ativismo Judicial e Políticas Públicas...................................207

Políticas Públicas E ATIVISMO JUdiCial: O DILEMa ENTRE EFETIVIDAde E LIMITES DE ATUAÇÃo............209 Ana Luisa Tarter Nunes, Nilton Carlos Coutinho e Rafael José Nadim de Lazari

Controle Judicial das Políticas Públicas: Perspectiva da hermenêutica filosófica e

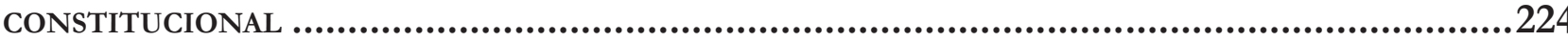

Selma Leite do Nascimento Sauerbronn de Souza

A atUAÇão do PODER JUdiciário NO ESTADO CONSTITUCIONAL EM FACE DO FENÔMENO DA JUDI-

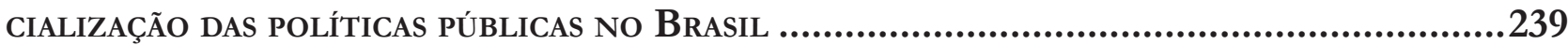

Sílvio Dagoberto Orsatto

Políticas PÚblicas E PROCESSO ELEITORAL: REFLEXÃo A PARTIR DA DEMOCRACIA COMO PROJETO POLÍTICO

Antonio Henrique Graciano Suxberger

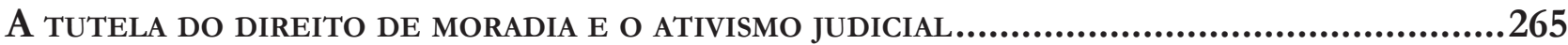

Paulo Afonso Cavichioli Carmona

Ativismo Judicial e Direito à Saúde: a judicialização das políticas públicas de saúde e os impactos da POStura ativista do Poder Judiciário.

Fernanda Tercetti Nunes Pereira

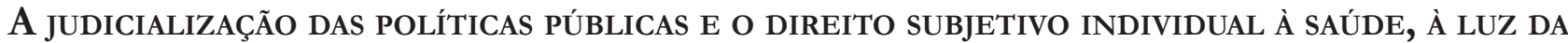
TEORIA DA JUSTIÇA DISTRIBUTIVA DE JoHN RAWLS

Urá Lobato Martins

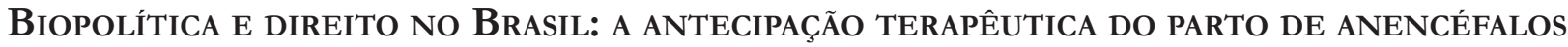
COMO PROCEDIMENTO DE NORMALIZAÇÃO DA VIDA

Paulo Germano Barrozo de Albuquerque e Ranulpho Rêgo Muraro

Ativismo judicial e judicialização da política da RelaÇão de Consumo: uma análise do CONTROLE JURISDicional dos CONTRATOS DE PLANOS DE SAÚDE PRIVAdo No ESTADo DE São

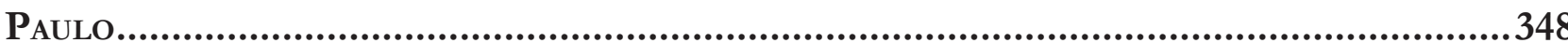
Renan Posella Mandarino e Marisa Helena D’Arbo Alves de Freitas 
A atuaÇão do Poder Judiciário na implementaÇão de políticas públicas: o caso da deMARCAÇÃO DOS TERRITÓRIOS QUILOMBOLAS ........................................................362 Larissa Ribeiro da Cruz Godoy

Políticas públicas e etNodesenVolvimento com ENFOQUe NA LEGISLAÇão INDigenista BRASILEIRA

Fábio Campelo Conrado de Holanda

Tentativas de contenção do ativismo judicial da Corte Interamericana de Direitos Humanos

Alice Rocha da Silva e Andrea de Quadros Dantas Echeverria

O desenvolvimento da Corte Interamericana de Direitos Humanos. .410 André Pires Gontijo

O ATivismo judicial da Corte Europeia de Justiça para alÉm da integração europeia...... 425 Giovana Maria Frisso

Grupo III - Ativismo Judicial e Democracia.....

Liberdade de Expressão e Democracia. Realidade intercambiante e necessidade de aprofundamento da Questão. Estudo comparativo. A jurisprudênCia do Supremo Tribunal Federal no Brasil- Adpf 130- e a Suprema Corte dos Estados Unidos da AmériCA.

Luís Inácio Lucena Adams

A germanística JuRídica e a metáfora do dedo EM Riste no CONTEXTO EXPLORATIVO das JUSTIFICATIVAS DA DOGMÁTICA DOS DIREITOS FUNDAMENTAIS

Arnaldo Sampaio de Moraes Godoy

Anarquismo Judicial e Segurança Jurídica Ivo Teixeira Gico Jr.

A (DES)hARMONIA ENTRE OS PODERES E O DiÁlOgo (IN)TENSO ENTRE DEMOCRACIA E REPÚBLI-

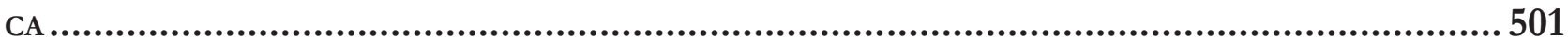

Aléssia de Barros Chevitarese

Promessas da modernidade e Ativismo Judicial. 519 Leonardo Zehuri Tovar

Por DENTRO DAS SUPREMAS CORTES: BASTIDORES, TELEVISIONAMENTO E A MAGIA DA TRIBUNA..... 538 Saul Tourinho Leal 
Direito Processual de grupos Sociais no Brasil: UMA VERsão REVISTA E ATUALIZADA DAS PRIMEIRAS LINHAS

Jefferson Carús Guedes

A OUTRA REALIDADE: O PANCONSTITUCIONALISMO NOS Isteites .

Thiago Aguiar de Pádua, Fábio Luiz Bragança Ferreira E Ana Carolina Borges de Oliveira

A resolução n. 23.389/2013 do Tribunal Superior Eleitoral E a tensão entre os podeRES CONSTITUÍDOS

Bernardo Silva de Seixas e Roberta Kelly Silva Souza

O RESTABELECIMENTO DO EXAME CRIMINOLÓGICO POR MEIO DA SÚMULA VINCULANTE $\mathrm{N}^{\circ}$ 26:

UMA MANIFESTAÇÃO DO ATIVISMO JUDICIAL .....................................................6 622

Flávia Ávila Penido e Jordânia Cláudia de Oliveira Gonçalves

Normas Editoriais .................................................................................6 637

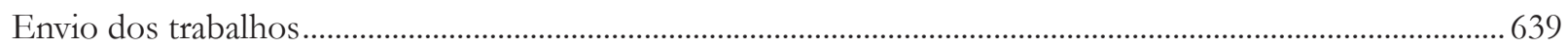




\title{
Direito processual de grupos sociais no Brasil: uma versão revista e atualizada das primeiras linhas*
}

\author{
Procedural law of social groups in Brazil: a \\ revised and updated version of the first lines
}

Jefferson Carús Guedes**

\section{Resumo}

Com caráter especulativo, o texto identifica a ampliação da tendência socializante do processo e seu alcance a outras áreas do direito material e do direito processual, para além do processual trabalhista e da seguridade social. Propõe nova forma de classificação dos ramos processuais não penais, em três áreas: os Processos para defesa dos Interesses Públicos on do Patrimônio Público, os Processo para defesa de interesses individuais privados e o Processo para defesa interesses individuais especiais, sob a denominação de "Direito Processual Social". Tal proposição decorre do exame da construção de leis especiais, principalmente a partir da década de 80, permitindo a formação de áreas especiais tal como o Direito Processual Previdenciário e Assistencial Social; Direito Processual do Consumidor; Direito Processual da Infância e Adolescência; Direito Processual dos Idosos; Direito Processual Acidentário e de Portadores de Deficiência.

Palavras-chave: Socialização do processo. Direito Processual Social. Defesa. Interesses individuais especiais. Acesso à justiça. Processo justo. Juizados especiais.

\section{Abstract}

In a speculative manner, the text identifies the extension of the trend of socializing process and its reach to other areas of substantive law and procedural law, beyond the procedural labor law and social security. It proposes new classifications for the non-criminal procedural branches of Law in three areas: Public Interest or Property Defense Procedural Law; Private Individual Interests Defense Procedural Law; Special Individual Interest Defense Procedural Law, under the denomination of "Social Procedural Law". Such proposition comes from a examination of the formation of special areas in law such as: Social Security and Assistence Procedural Law; Consumer Procedural Law; Childhood and Adolescence Procedural Law; Elderly Procedural Law; Accident and Disability procedural Law.

Keywords: Socialization of procedural law. Social Procedural law. Special individual interests defense. Access to justice. Fair process. Special courts.

** Professor da Graduação, Especialização, Mestrado e Doutorado do UniCEUB. Doutor e Mestre em Direito Processual Civil (PUC$\mathrm{SP})$. Advogado da União. E-mail: professor.

carusguedes@gmail.com
* Recebido em 30/10/2014

Aprovado em 25/02/2015 


\section{Observação sobre a atualização e introdução}

Passados oito anos da divulgação da versão original deste artigo, publicado em 2006 na Revista Latinoamericana de Derecho Social, n. 2, (México: UNAM) e na Revista de Processo, n. 142, (São Paulo: Revista dos Tribunais) surge a necessidade de atualizar alguns dados.

A motivação para a atualização e revisão se amplia pelo extenso debate atual sobre o 'ativismo' e o 'garantismo', sintetizado, no Brasil, no livro 'Ativismo' Judicial e o Garantismo Processual, coordenado pelos professores Fredie Didier, José Renato Nalini, Glauco Gumerato Ramos e Wilson Levy. ${ }^{1}$ Nessa obra coletiva, foi incluído um outro artigo de nossa autoria que remete a este Direito Processual Social que a nosso ver se situa em posição intercalar, entre as duas 'alternativas' oferecidas no título do referido livro. O título do artigo publicado nessa obra coletiva em 2013 é Direito Processual Social atual: entre o 'ativismo' judicial e o garantismo processual. ${ }^{2}$

Deve-se destacar como introdução que não há, desde algumas décadas no Brasil, referência, em extensão e profundidade, a um dito Sistema ou Direito Processual Social, pelo menos do modo que se tentará identificar e apresentar neste estudo, aproveitando-se principalmente as proposições dos processualistas mexicanos, dentre os quais o professor José Ovalle Favela, que arrola dentro dessa área do processo o Direito Processual do Trabalho, o Direito Processual Agrário e o Direito Processual da Seguridade Social. ${ }^{3}$ O que se faz, desde então, ao propor a denominação desse ramo processual, é tomar por empréstimo parte da expressão mexicana, sabendo que a importação de ideias e classificações técnico-processuais possui inúmeros riscos de equívocos e de incongruências, mais ainda, quando essas ideias são construídas com base em interpretações de leis originadas em outros sistemas, não contrastadas com o sistema jurídico nacional. Essa advertência inicial poderia impedir o prosseguimento nessa curta especulação sobre a existência ou para a identificação de um Direito Processual Social (2008) ou agora Direito Processual de Grupos Sociais (2014).

As referências antes existentes eram esparsas e remotas, e estavam relacionadas especialmente ao Direito Processual do Trabalho, como direito instrumental ao Direito do Trabalho, também denominado Direito Social. Essas referências específicas ao Direito Social são encontráveis no período histórico de positivação dos direitos trabalhistas. Uma tal concepção inicial sofria visível restrição contextual, e pelas mesmas razões, se diferenciava do que se pretende expor neste estudo. O professor Cesarino Junior, desde a década de 1940, com seu magistério e as sucessivas edições da obra Direito Social brasileiro, estabeleceu conceito de Direito Social, ${ }^{4}$ definindo-o como a área na qual estavam inseridos o Direito Coletivo Social, o Direito Previdencial e o Direito Social Individual, este subdividido em Direito do Trabalho e Direito Assistencial. Por conseguinte, poder-se-ia extrair dessa classificação as correspondentes áreas processuais, na medida em que se fossem formando.

Não se trata neste momento de afirmar o caráter social ou socializado do direito processual do trabalho e da seguridade social, mas apontar, ainda que de modo incipiente, a ampliação dessa tendência socializante do processo e seu alcance a outras áreas do direito material e do direito processual. Pelas observações iniciais, este trabalho segue por um caminho de risco, e ainda que não contenha em si grandes novidades, pode propor, ao fim, uma nova forma de classificar os ramos processuais. A proposição original e central é outra

1 DIDIER JR., Fredie et al.(Coord). 'Ativismo' judicial e o garantismo processual. Salvador: JusPodivm, 2013. O mesmo artigo está também publicado na Revista Brasileira de Direito Processual, n. 82, abr./jun. 2013.

2 A suposta posição espacial daquele Direito Processual Social (ou de certos grupos sociais) de estar 'entre 'um e outro modo de atuação judicial ou em uma posição nitidamente 'intercalar', 'interlocutória', intermediária, traz inúmeras desvantagens teóricas para a sua definição.

3 Teoria General del Proceso, item n. 2.6, p. 62-70. SANTOS AZUELA, Héctor. La teoria general del proceso en el sistema del Derecho Procesal Social. Boletin Mexicano de Derecho Comparado, Mexico (DF), v. 34, n.101, p. 567-588, may./ago. 2001. Disponible em: <http://biblio.juridicas.unam.mx/revista/pdf/DerechoComparado/101/art/art6.pdf>. Acceso em: 26 abr. 2002.

4 CESARINO JUNIOR e Marly CARDONE conceituavam o Direito Social como "a ciência dos princípios e leis geralmente imperativas, cujo objetivo imediato é, tendo em vista o bem comum, auxiliar as pessoas físicas, dependentes do produto do seu trabalho para a subsistência própria e de suas famílias, a satisfazerem as necessidades vitais e a ter acesso à propriedade privada", Direito Social, v. I, item n. 1.16, p. 36-37. CESARINO JUNIOR, A. F.; CARDONE, Marly. Direito social. 2. ed. São Paulo: LTr, 1993. v. 1. 
e está voltada ao exame da construção dessas leis e da legislação hoje vigente, para nela identificar, segundo critérios próprios da Teoria do Processo e de outras áreas congêneres ao Direito, critérios novos de classificação, bem como a validade e utilidades dessas novas categorias de direitos processuais.

Essa nova classificação posiciona o Direito Processual de Grupos Sociais (DPGS) entre dois grandes pilares ou forças, entre o público e o privado, entre a rua e a casa, entre o indisponível e o disponível, entre o Estado e a sociedade.

\section{EstáGIOS EVOLUTIVOS RECENTES NO DIREITO PROCESSUAL BRASILEIRO}

Sabe-se quão rápida tem sido a evolução da sociedade brasileira, sejam considerados os indicadores demográficos, os dados econômicos, os aspectos sociais, assim como as mudanças políticas acontecidas nas últimas cinco décadas do séc. XX e nas décadas iniciais do século XXI.

O direito material e o direito processual não estão imunes a essas mudanças e as alterações da vida social sofrem os mais diversos e numerosos reflexos, ora sob impacto que pode ser considerado de cunho ideológico pelas elites e por sua representação social, ora sob a forma de pressão direta da sociedade, com conteúdo ideológico às vezes inverso. Figuram como exemplos de um e de outro conjunto de forças certas normas especiais do sistema financeiro e a dos juizados especiais de 'pequenas causas', sucessivamente. ${ }^{5}$ Válido então que se descrevam cronologicamente essas mudanças, para que se note a expressão e a profundidade delas.

\subsection{Evolução do direito processual nas últimas décadas}

Como mencionado, ainda que pesem as opiniões contrárias, foi rápida a evolução do direito processual que incorporou nas últimas décadas inovações significativas, desmistificadoras de alguns dogmas construídos ou incorporados pelo direito processual civil no Brasil.

Ainda na vigência do CPC de 1939, observou-se a incorporação de leis que podem ser apontadas como inversoras da visão individualista e liberal do processo, tal como Consolidação das Leis do Trabalho (CLT), introdutora de inúmeras modificações simplificadoras, que viriam sucessivamente a ser estendidas para outras áreas do processo. ${ }^{6}$

Em sentido paralelo, surgiu o Dec. 7.661/1945, que regrava o processo falimentar, a Lei de Assistência Judiciária Gratuita (Lei n. 1.060/1950), a qual ampliou o acesso ao Judiciário — sem o pagamento de custas, permitindo que os comprovadamente pobres pudessem ser desonerados dos riscos e encargos econômicos do processo —, seguida pela Lei do Mandado de Segurança (Lei n. 1.533/1951), com procedimento especial, sumário e documental para defesa de direito líquido e certo não amparado por habeas corpus. Já em outro plano, como forma de proteção aos interesses públicos, surge e a Lei da Ação Popular (Lei n. 4.717/1965); no plano privado, no âmbito do direito de família, a Lei de Alimentos (Lei n. 5.478/1968) e, no plano da defesa de interesses patrimoniais de instituições financeiras, o Decreto-lei com procedimento para reaver bens alienados fiduciariamente (Dec-lei n. 911/1969). ${ }^{7}$

5 Decreto 911/1969 e Lei n. 7.244/1984. A constatação da natureza ideológica da primeira norma foi apontada por Carlos Alberto Álvaro de Oliveira no texto Procedimento e ideologia no direito brasileiro atual. OLIVEIRA, Carlos Alberto Álvaro. Procedimento e ideologia no direito brasileiro atual. In: TUBENCHLAK, James; BUSTAMENTE, Ricardo (Coord). Livro de estudos jurídicos. Rio de Janeiro: Instituto de Estudos Jurídicos, 1992. v. 4, p. 181-187.

6 Essa observação não se opõe àquela que aponta as fragilidades técnico-doutrinárias da legislação processual trabalhista, especialmente aquelas relacionadas à linguagem e à necessidade da aplicação subsidiária do CPC, diante das omissões da CLT. Ver LIMA, Alcides de Mendonça. Processo civil no processo trabalhista. São Paulo: LTr, 1983. p. 17-27.

7 Essa expansão dos procedimentos especiais, criados paralelamente ao CPC de 1939 (1939-1973) é notada também na vigência 
Depois, já sob a vigência do CPC de 1973 (o Anteprojeto Buzaid foi publicado em 1964), houve sucessivas e significativas mudanças em leis especiais: Lei do Divórcio (Lei n. 6.515/1977), Lei de Execução Fiscal (Lei n. 6.830/1980), Lei dos Juizados de Pequenas Causas (Lei n. 7.244/1984); com a edição da Lei n. 8.884/1994, criam-se novas formas de tutela e instrumentos processuais dirigidos à defesa da ordem econômica, e a Lei da Ação Civil Pública (Lei n. 7.347/1985), voltada à tutela do meio ambiente, interesses difusos e coletivos, também estendida à tutela da ordem econômica pela Lei n. 8.884/1994 (art. 88).

A Constituição Federal de 1988 introduziu institutos como o babeas data, o mandado de injunção e o mandado de segurança coletivo, destinados à tutela constitucional das liberdades, mas também assegurou extensa lista de direitos constitucionais processuais, como: o contraditório; a ampla defesa; o devido processo; o duplo grau de jurisdição; a igualdade; o dever de motivar decisões; a proibição da prova ilícita; a inafastabilidade do controle judicial; o juiz natural; a publicidade. Mais que isso, constitucionalizou a tutela jurisdicional coletiva (legitimidade dos sindicatos e das entidades associativas em geral: art. $5^{\circ}$, inc. XXI, e art. $8^{\circ}$, inc. III); os juizados especiais (art. 24, inc. X, e art. 98, inc. I) e a ação civil pública (art. 129, inc. III).

A seguir, acresceram-se o Estatuto da Criança e do Adolescente (Lei n. 8.069/1990) e o Código de Defesa do Consumidor (Lei n. 8.078/1990). Seguiu-se a década de 1990, com a Lei de Improbidade Administrativa (Lei n. 8.429/1992), Lei dos Juizados Especiais Cíveis e Criminais (Lei n. 9.099/1995), Lei da Arbitragem (Lei n. 9.307/1996), Lei do Habeas Data (Lei n. 9.507/1997), Lei da ADI e ADC (Lei $n$. 9.868/1999), Lei da Arguição de descumprimento de preceito fundamental (Lei n. 9.882/1999), Estatuto da Cidade (Lei n. 10.257/2001), Lei dos Juizados Especiais Federais (Lei n. 10.259/2001), o novo Código Civil (Lei n. 10.406/2002), o Estatuto do Idoso (Lei n. 10.741/2003), normas que, em maior ou menor extensão, introduzem ou alteram conceitos de direito processual, criando áreas específicas de proteção especial.

Mais recentemente a Lei dos Juizados da Fazenda Pública (Lei n. 12.153/2009), a nova Lei do CADE (Lei n. 11.529/2011), o Estatuto da Igualdade Racial (Lei n. 12.228/2010), o Estatuto da Juventude (Lei n. 12.852/2013) que criam, recriam e expandem instrumentos processuais diferenciados que podem - em certos casos - se encaixar nessa categoria de Direito Processual de Grupos Sociais.

Não se pode também deixar de apontar que esse processo evolutivo tem suas razões políticas, sociais e ideológicas, além de uma conexão estreita com o estágio de desenvolvimento cultural da nação.

Para a avaliação das razões desse progresso legal, ter-se-ia de penetrar no exame de questões não jurídicas e propriamente ideológicas, como já notou a Carlos Alberto Alvaro de Oliveira quando trata sobre:

[...] esse rápido bosquejo da legislação processual especial que se formou em nosso país após 1964, de modo bastante significativo em sua grande parte baixada por decretos-lei, em confronto com as normas comuns do processo civil brasileiro, impõe meditação aprofundada. O seu exame evidencia de que forma os grupos que empolgam o Poder se apropriam de instrumentos mais eficientes à satisfação de suas pretensões, relegando para segundo plano as aspirações da maior parte da população. ${ }^{8}$

Esse não é um fenômeno exclusivamente brasileiro. Na Argentina foi observado desenvolvimento equivalente, sempre associando às alterações nas regras processuais com as mudanças na sociedade; notou-se tendência de publicização do processo, valorização da oralidade, tendência de socialização do processo e a livre valorização da prova. ${ }^{9}$ Também na doutrina portuguesa se observou o mesmo:

do CPC de 1973 (1974-2014), como forma de fuga de um procedimento padronizado que não atende a especificidades relacionadas a pessoas e bens envolvidos nos litígios. Ver: MARINONI, Luiz Guilherme Teoria geral do processo. 4. ed. São Paulo: Revista dos Tribunais, 2010. p.430-434.

8 OLIVEIRA, Carlos Alberto Álvaro. Procedimento e ideologia no direito brasileiro atual. In: TUBENCHLAK, James; BUSTAMENTE, Ricardo (Coord). Livro de estudos jurídicos. Rio de Janeiro: Instituto de Estudos Jurídicos, 1992. v. 4, p. 186. Associa essas mudanças ao período da ditadura militar no Brasil. Em obras mais extensas: PORTANOVA, Rui. Motivaçoes ideológicas da sentença. Porto Alegre: Livraria do Advogado, 1992. E SILVA, Ovídio A. Baptista da. Processo e ideologia. Rio de Janeiro: Forense, 2004.

9 NOGUEIRA, Carlos Alberto. Las transformaciones del proceso civil y la política procesal. In: BERIZONCE, Roberto O. et al. La justicia entre dos épocas. Buenos Aires: LEP, 1983. p. 15-56. 
[...] no actual contexto e produção legislativa, surgem-nos quase diariamente novos processos suscitando uma ampliação diversificada de toda a realidade processual que urge conhecer a quem queira compreender, dentro dela, o próprio processo civil. Deve, aliás, notar-se que esta expansão da realidade que privilegia o aparecimento de novos processos ou a própria reforma de processos conservados, uns e outros diferentes dos civis, é, de algum modo, explicada não só por razões ideológicas próprias de uma produção legislativa tendente à consolidação do Poder instituído, como suscitada pelo amadurecimento social de novas relações conflituais. ${ }^{10}$

$\mathrm{Na}$ Espanha foi observado a mesma expansão associada a amplitude do direito privado, às modificações sociais, à desconfiança em relação ao procedimento ordinário, motivos considerados variados e heterogêneos, mas dissociados de componentes ideológicos. ${ }^{11}$

Todos esses autores, examinando realidades diferentes como a brasileira, a argentina e a portuguesa e espanhola, identificam fenômenos com consequências assemelhadas, nascidas da ampliação e especificação da conflituosidade social, presente em sociedades mais complexas, que influenciam o processo, enquanto produto cultural que resulta da vida social.

\subsection{Processo civil e respostas às demandas sociais: a visão histórica da doutrina}

Para a compreensão do fenômeno evolutivo do processo civil, é importante que se perpasse pela posição dos expoentes doutrinários que associaram o desenvolvimento histórico das regras processuais a fatores ou demandas sociais e também a fatores ideológicos.

Galeno Lacerda, processualista que se dedicou principalmente ao estudo do processo cautelar, não deixou de observar em mais de uma ocasião a vinculação do processo ao estágio cultural do país ${ }^{12}$ e indicar que:

[...] uma das marcas mais características do Direito brasileiro, na atualidade, consiste na abertura para o social a partir da Constituição de 1988.

Esse autor aponta como razões da mudança as exigências da vida moderna, momento no qual os homens passaram a viver numa sociedade de massas que exigiram o rompimento das barreiras do conservadorismo jurídico representado pelo processo individualista. ${ }^{13}$ Distingue como exemplos os dissídios coletivos e suas sentenças normativas no processo trabalhista desde a década de 1940; os efeitos erga omnes da sentença na ação popular e na ação civil pública; as ações coletivas do Código de Defesa do Consumidor (Lei 8.078/1990), para defesa de interesses difusos, coletivos e individuais homogêneos; as ações coletivas previstas no Estatuto da Criança e do Adolescente (Lei 8.069/1990) e a extensão da legitimação para a proposição das ações de entes coletivos em defesa de seus associados ou filiados.

Ada Pellegrini Grinover, professora da USP dedicada tanto ao estudo do processo civil como penal, identificou entre os esforços dos processualistas:

[...] a transformação do processo, de instrumento meramente técnico, em instrumento ético de atuação da Justiça e de garantia da liberdade; a partir desta visão externa, a percepção da necessidade da plena e total aderência do sistema processual à realidade sócio-jurídica a que se destina, cumprindo sua primordial vocação, que é de servir de instrumento a efetiva realização dos direitos. ${ }^{14}$

Aponta ainda como iniciativa pioneira nessa tendência a adaptação do processo individual do trabalho, que rompeu o esquema tradicional do processo civil,

10 MARTINS, Soveral. Processo e direito processual. Coimbra: Centelha, 1985. v. .1. p. 11.

11 GONZALEZ GARCIA, Jesús María. La proliferación de processos civiles. Madrid: McGranw-Hill, 1996. p. 88-93.

12 LACERDA, Galeno. Processo e cultura. Revista de Direito Processual Civil, São Paulo, v. 2, n. 3, p.74-86, jan./jun. 1961.

13 LACERDA, Galeno. Eficácia da prestação jurisdicional no atendimento às demandas sociais. In: CARVALHO, Carlos Henquie (Colab.). Uma vida dedicada ao direito: homenagem a Carlos Henrique de Carvalbo: o editor dos juristas. São Paulo: Revista dos Tribunais, 1995. p. 173-182. p. 229-230.

14 GRINOVER, Ada Pellegrini. Deformalização do processo e deformalização das controvérsias. In: GRINOVER, Ada Pellegrini. Novas tendências do direito processual. 2. ed. Rio de Janeiro: Forense Universitária, 1990. p. 175-204. p. 178. Trabalho originalmente apresentado no VIII Congresso Internacional de Direito Processual, no ano de 1987. 
[...] abrindo caminho para a socialização do processo, por força da atribuição de poderes de direção e controle mais amplos ao juiz, da adoção de uma concreta igualdade de partes (desde o acesso à Justiça até a paridade de armas dos litigantes, implementada pelo juiz) e do esforço em busca da conciliação, num exemplo marcante de transformação do processo, rumo a um grau mais elevado de deformalização, democratização e publicização. ${ }^{15}$

A autora destaca, ainda, as características do CPC de 1973 que se coadunam com essa tendência e especialmente os Juizados Especiais de Pequenas Causas, criados pela Lei n. 7.244/1984, caracterizados pelos critérios da oralidade, gratuidade, simplicidade e economia; com participação de juízes leigos, árbitros e conciliadores e o incentivo à conciliação.

Ovídio Baptista da Silva, processualista gaúcho, elogiado pela sua ousadia e originalidade, orientou toda a sua obra para uma crítica constante às estruturas do processo civil, influenciadas pelo racionalismo e incapazes de atender às demandas sociais, incompatíveis com o desenvolvimento da cultura e da história. Ao comentar a Lei dos Juizados Especiais de Pequenas Causas (Lei n. 7.284/1984), o autor enfrentou a maioria das objeções que contra ela se opunham, destacando o ${ }^{16}$ :

acesso à justiça dos litigantes, evidentemente não apenas aqueles que o sentido da palavra carente costuma significar, indicando simplesmente os economicamente débeis, mas abrangendo todas as verdadeiras carências, enquanto efetiva e concreta desproporção de armas perante a pugna jurídica.

\section{E acrescenta:}

São notórias e antigas, aliás, as críticas que se fazem às formas tradicionais de positivismos legalistas, próprias da civilização burguesa liberal, produtoras de sistemas jurídicos que proclamam a defesa de liberdades e igualdades apenas abstratas e formais, enquanto permitem e protegem, na triste realidade social de todos os dias, as mais inomináveis desigualdades religiosas, econômicas, raciais e políticas, naturalmente refletidas numa tutela processual apenas formal e retórica, na medida em que aceleradamente, distancia-se da vida social real, presa que está a um universo conceitual de muito superado" [...] Ora, não é segredo para ninguém que nosso paradigmático e exacerbadamente lerdo processo ordinário é uma técnica eminentemente conservadora, na medida em que privilegia, em geral, a parte economicamente mais forte (Cappelletti, Proceso, ideologias, sociedad, pág. 276), capaz de resistir anos a fio a uma discussão sábia sem dúvida e instrutiva, mas de pouquíssimos resultados sociais visíveis. ${ }^{17}$

Criticava a incapacidade do processo em atender às demandas sociais, diante das deficiências técnicas dos instrumentos processuais utilizados, pois construídos sob influência ou hegemonia social de camadas liberais burguesas. Conclui, elogiando a lei das pequenas causas:

Podemos, portanto, resumir os propósitos fundamentais almejados pelo novo instituto, que agora se busca inserir no ordenamento jurídico-processual brasileiro, unindo-os nesse exclusivo objetivo: ampliação da base efetiva da tutela jurisdicional prometida e jamais outorgada pelos sistemas processuais

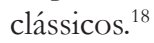

Arruda Alvim enfrentou o tema pioneiramente em artigo publicado na Revista de Processo n. 64, intitulado Anotações sobre as perplexidades e os caminhos do processo civil contemporâneo, texto refundido e ampliado no Manual de Direito Processual Civil, item n. 21-A, sob a denominação de $A$ s tendências atuais do processo civil — $A$ socialização do processo civil — A fase hodierna do processo civil brasileiro. ${ }^{19} \mathrm{O}$ autor descreve as perplexidades a partir da identificação da convivência simultânea de dois sistemas, sendo um moderno e outro com

estrutura do que designamos de processo clássico, as funções desempenhadas, rigidamente separadas, de que se constitui um exemplo o vigente Código de Processo Civil, na sua estrutura originária. Há

15 GRINOVER, Ada Pellegrini. Deformalização do processo e deformalização das controvérsias. In: GRINOVER, Ada Pellegrini. Novas tendências do direito processual. 2. ed. Rio de Janeiro: Forense Universitária, 1990. p. 175-204. p. 180.

16 SILVA, Ovídio A. Baptista da. Juizado de pequenas causas. Porto Alegre: Letras Jurídicas, 1985. p. 19-21.

17 SILVA, Ovídio A. Baptista da. Juizado de pequenas causas. Porto Alegre: Letras Jurídicas, 1985. p. 19-21.

18 SILVA, Ovídio A. Baptista da. Juizado de pequenas causas. Porto Alegre: Letras Jurídicas, 1985. p. 21.

19 ALVIM NETTTO, José Manuel de Arruda. Anotações sobre as perplexidades e os caminhos do processo civil contemporâneo. Revista de Processo, São Paulo, v. 16, n. 64, p. 217-246, out./dez. 1991. 
pontos ou setores de estrangulamento que têm demandado alteração nesse sistema, porque deixou de atender às expectativas sociais. ${ }^{20}$

Os pontos de estrangulamento existentes no processo clássico foram destacados como: a) as custas judiciais; b) a inexistência das Cortes menores (Juizados Especiais) destinadas a facilitar o acesso à Justiça; c) a inabilitação ou incapacidade de uma das partes para defender-se; d) a definição de interesses difusos e coletivos capazes de serem utilmente defendidos; e) incentivo à transação como forma de atender a conflituosidade excessiva existente em relações duráveis e continuativas.

Disso decorre a incapacidade (insuficiência) de o processo clássico, individualista e com rígida divisão das funções (conhecimento, cautelar e executiva) atender satisfatoriamente às novas demandas e às alterações sofridas pela sociedade no período posterior às duas Grandes Guerras.

Cândido Dinamarco, profícuo pesquisador do processo civil, desde as suas proposições iniciais na década de 1980, vem orientado para a mudança na interpretação da função do processo, visto por ele como instrumento técnico objetivando, o atendimento dos fins (escopos) sociais. Na obra $A$ instrumentalidade do processo arrola os escopos da jurisdição e do processo, como o jurídico, o político e o social, este voltado a eliminar conflitos com critérios justos, com adaptação das técnicas processuais que se vão

agitando nos últimos tempos, com vistas a adaptar-se às exigências sociais e políticas que atuam sobre o sistema processual e lhe cobram o cumprimento de seu compromisso com o Estado e com a própria sociedade $^{21}$

\section{E acrescenta:}

E assim é que ao lado das disposições tradicionais do direito processual civil e mesmo na sua interpretação teleológica, vão surgindo soluções reveladoras de uma sensibilidade social antes inexistente. [...] São institutos simplificadores, para a brevidade dos juízos e maior participação dos juízes e das próprias partes, tudo visando a formar uma maior convicção mais aderente à realidade social dos conflitos e conduzir à pronta pacificação indispensável à legitimação social do próprio sistema. [...] A aproximação da justiça à população, feita sem os intuitos demagógicos e corporativistas denunciados quanto a uma conhecida tentativa europeia recente, é um dos pontos cardeais de uma 'nova política judiciária' compatível com as exigências do tempo e com a visão pluralista dos objetivos do processo. ${ }^{22}$

Barbosa Moreira tem dedicado boa parte de sua obra para a reflexão comparatista, ${ }^{23} \mathrm{e} o$ faz levando às outras nações a experiência que se tem produzido no Brasil, nas últimas décadas, mas também trazendo de outros a experiência para neste estudo confrontá-la à nossa. Ao apontar "Os novos rumos do processo civil brasileiro", no ano de 1994, descreve sinteticamente a evolução do processo civil, que só,

pouco a pouco, foi-se tomando consciência mais clara da ligação entre problemas processuais e as mil condicionantes políticas, sociais, econômicas, do contexto histórico em que a atividade judicial é convocada a exercer-se. ${ }^{24}$

Mas com acuidade identificava que:

nenhum observador isento deixará de reconhecer a fina sensibilidade da moderna ciência do processual brasileira aos valores sociais. A temática da proteção jurisdicional dos interesses supra-individuais, v.g., produziu entre nós acervo quiçá tão abundante — se bem que de qualidade muito variada — quanto em países de mais ricas tradições culturais e jurídicas. Nessa e em outras áreas, mostra-se a doutrina, em

20 ALVIM NETTO, José Manuel de Arruda. Manual de direito processual civil. 15. ed. São Paulo: Revista dos Tribunais, 2012 . p. 78.

21 DINAMARCO, Cândido Rangel. Instrumentalidade do processo. 3. ed. São Paulo: Malheiros, 1993. p. 226.

22 DINAMARCO, Cândido Rangel. Instrumentalidade do processo. 3. ed. São Paulo: Malheiros, 1993. p. 227.

23 Sua obra extensa tem notoriedade desde o clássico Novo Processo Civil brasileiro (22. ed., 2005) e, especialmente, nos Comentários do CPC, v. VIII (Recursos), além dos Temas de direito processual, séries 1. a 8., obra que reúne artigos avulsos, conferências, comentários etc. MOREIRA, José Carlos Barbosa. Os novos rumos do processo civil brasileiro. In: MOREIRA, José Carlos Barbosa. Temas de direito processual: sexta serie. São Paulo: Saraiva, 1997. p. 193-208.

24 MOREIRA, José Carlos Barbosa. Os novos rumos do processo civil brasileiro. In: MOREIRA, José Carlos Barbosa. Temas de direito processual: sexta serie. São Paulo: Saraiva, 1997. p. 193-208. p. 195. 
geral, consciente de utilizar os instrumentos do nosso ofício para melhor ajustar às realidades e carências da hora a maneira por que funciona a máquina judiciária. ${ }^{25}$

Teresa Arruda Alvim Wambier, em obra que sintetiza mais de dez anos de pesquisa sobre o controle das decisões judiciais, manifesta já na introdução a tendência evolutiva do direito, que se reflete no processo e no modo de decidir dos juízes, no qual observa que o "Estado meramente espectador vem passando a ser Estado preocupado com as demandas sociais". Nesse momento histórico ocorre uma dita "revolução de valores" em que camadas antes marginalizadas passam a ocupar os "centros de decisão. ${ }^{26}$ Essa afirmação coincide com a expansão do direito processual de grupos sociais.

Luiz Guilherme Marinoni em sua Teoria Geral do Processo identifica uma nova concepção do direito de ação surgida

não apenas porque se percebeu que o exercício da ação poderia ser comprometido por obstáculos sociais e econômicos, mas também porque se tomou consciência de que os direitos voltados a garantir uma nova forma de sociedade, identificados nas Constituições modernas, apenas poderiam ser concretizados se garantido um real — e não ilusório — acesso à justiçç. ${ }^{27}$

Em todos se nota a consciência de que o direito processual, enquanto técnica e método, modifica-se ao sabor das influências culturais, políticas, econômicas e até ideológicas para atender a demandas de grupos sociais por seus direitos e por justiça.

Uma nova geração de processualistas vem identificando novas e mais profundas mudanças no processo civil, agora marcado mais profundamente pelas influências constitucionais e pela aplicação mais ampla de princípios. Pode-se destacar dentre esses Fredie Didier Junior, ${ }^{28}$ Eduardo Cambi, ${ }^{29}$ Daniel Mitidiero, ${ }^{30}$ Antonio do Passo Cabral.

\section{TEORIA DO PROCESSO E TEORIA DOS PROCEDIMENTOS}

A observação de Eduardo J. Couture transcrita abaixo permite que se insista na possibilidade do estudo de uma ciência processual com núcleo comum, sem comprometimento com a existência ou não de uma teoria geral, pois

a ciência do processo não tem como objeto de conhecimento somente os atos processuais: as petições, as provas, as apelações, as execuções, as formas e os prazos. Essa concepção errônea fez o filósofo pensar que sobre essa base não se pode construir uma ciência de conhecimento do real com validade universal. A ciência do processo se assenta sobre substâncias menos frágeis. É provável que, mediante um esforço de abstração, seja possível assinalar algumas proposições sobre a própria essência do processo, não sobre a sua exterioridade. Essas proposições devem estabelecer a ligação do processo com o direito. ${ }^{31}$

A Teoria Geral do Processo, desde sua formulação original, sofreu críticas corrosivas, sendo mais contundente a que previa para cada ramo do processo uma própria teoria, em razão dos seus princípios individuais

25 MOREIRA, José Carlos Barbosa. Os novos rumos do processo civil brasileiro. In: MOREIRA, José Carlos Barbosa. Temas de direito processual: sexta serie. São Paulo: Saraiva, 1997. p. 193-208. p. 202-203.

26 WAMBIER, Teresa Arruda Alvim. Controle das decisões judiciais por meio de recursos de estrito direito e de ação rescisória. São Paulo: Revista dos Tribunais, 2001.p. 22-23.

27 MARINONI, Luiz Guilherme Teoria geral do processo. 4. ed. São Paulo: Revista dos Tribunais, 2010. p. 188-189.

28 DIDIER JR., Fredie. Os três modelos de direito processual: inquisitivo, dispositivo e cooperativo. In: LEITE, George Salomão; SARLET, Ingo Wolfgang; CARBONELL, Miguel (Coord.). Direitos, deveres e garantias fundamentais. Salvador: JusPodivm, 2011. p. 427-439.

29 CAMBI, Eduardo. Neoconstitucionalismo e neoprocessualismo: direitos fundamentais, políticas públicas e protagonismo judiciário. São Paulo: Revista dos Tribunais, 2010.

30 MITIDIERO, Daniel Francisco. Colaboração no processo civil: pressupostos sociais, lógicos e éticos. São Paulo: Revista dos Tribunais, 2009. p. 63-102.

31 Couture, Eduardo J. Fundamentos de derecho procesual civil. 3. ed. Buenos Aires: Depalma, 1976. p. 484. 
e de sua evolução específica. Ainda assim, não se impediu o desenvolvimento de uma proposta de teoria geral, amparado na busca de identidade de princípios gerais do processo e na indivisibilidade da jurisdição.

\section{Como sintetiza Cândido Dinamarco:}

Reconhece-se, em resumo, que existe muito em comum entre os diversos ramos processuais e que as peculiaridades de cada um não são suficientes a impedir ou a tornar menos frutífero o exame global dos grandes princípios, dos institutos fundamentais e do método comum - tudo num plano de plena aplicação a todos eles. ${ }^{32}$

Há processualistas civis e penais que admitem ${ }^{33}$ e outros que não admitem ${ }^{34}$ a viabilidade dessa Teoria Geral do Processo ou a preservação do processo em unidade, partindo principalmente da insustentabilidade do conceito de lide no processo penal. Excluído o direito processual penal, restringindo-se o olhar à jurisdição civil, em toda a sua amplitude — ou mais adequadamente à jurisdição não penal — pode-se, então, encontrar outros meios ou critérios de classificação dos processos, sem os percalços e vicissitudes inevitáveis na construção de uma teoria geral.

No campo não penal a identidade entre os ramos é maior, mesmo quando novas técnicas, novos processos ou novos procedimentos especiais surgem ou quando se amplia a tendência à diferenciação da tutela dos direitos em cada um desses ramos. ${ }^{35}$

Há fenômenos contemporâneos que devem ser observados: o rompimento da noção de ação abstrata única, a multiplicação das variantes processuais, identificadas com as ramificações do direito material; a tutela adequada e diferenciada e, também, uma expansão da quantidade de procedimentos especiais não codificados. Observando-se essa tendência, é possível constatar hoje no Brasil normas e doutrina em direito processual constitucional, direito processual tributário, direito processual agrário, direito processual ambiental etc. Rompe-se definitivamente a ideia transitória de que um procedimento único e geral poderia atender a especificidade de toda e qualquer pretensão material; ideia associada à tentativa de universalização do procedimento comum ordinário, enquanto meio técnico eficaz para a condução (satisfação) de todo e qualquer interesse em juízo.

Em parte essa multiplicação procedimental decorre de uma generalizada insatisfação com os procedimentos tradicionais (no Brasil o procedimento comum ordinário do $\mathrm{CPC}$ ) e, de outro, pela necessidade de criação de procedimentos especiais dirigidos a causas com interesse ou relevância social, como apontaram Mauro Cappelletti e Brian Garth na obra Acesso à Justiça. ${ }^{36}$ Esses autores denominam essa última tendência como desvio especializado que, ao lado dos novos tribunais voltados às causas especiais, são técnicas para escapar aos tribunais e juízos tradicionais. Apontam a notória outorga de direitos substantivos a grupos ou indivíduos considerados 'fracos' e à inadequação inclusive dos sistemas de litigação coletiva, marcados pela complexidade e pelo estigma adversarial ou do contraditório. E avançam para propor que

32 DINAMARCO, Cândido Rangel. Instituições de direito processual civil. São Paulo: Malheiros, 2001. v. 1. p. 51.

33 Admitem a existência da Teoria Geral do Processo, partindo de premissas de que "é una a jurisdição, expressão do poder estatal igualmente uno, uno também é o direito processual, como sistema de princípios e normas para o exercício da jurisdição CINTRA, Antonio Carlos Araújo; GRINOVER, Ada Pellegrini; DINAMARCO, Cândido Rangel. Teoria geral do processo. 20. ed. São Paulo: Malheiros, 2004. p. 48. Ou como um "conjunto de conceitos sistematizados (organizados) que serve aos juristas como instrumento de conhecer os diferentes ramos do direito processual” Rocha, José de Albuquerque. Teoria geral do processo. 7. ed. São Paulo: Atlas, 2003. p.18.

34 Tal resistência decorre, segundo autores como Ovídio A. Baptista da Silva e Fábio Gomes diferenciação na evolução da ciência, com consequente autonomia das áreas; b) a unidade é indiscutível, mas suas manifestações e modos de desenvolvimento correspondem a mesma diversidade dos objetos a que se referem; c) os conceitos fundamentais - exemplo - a possibilidade jurídica do pedido para o processo civil e penal não são conceitos idênticos. Silva, Ovídio Araújo Baptista da; GOMES, Fábio. Teoria Geral do Processo civil. 2. ed. São Paulo: Revista dos Tribunais, 2000. p. 38. E em Rogério Lauria Tucci: a) o processo penal não objetiva remover desacordo entre acusador e acusado; b) objetivo da ação estatal (pena) não poderia ser alcançado pelo contrato; c) revogabilidade do ato decisório; d) exigência de contraditório real; e) no processo penal não preexiste lide (lide material). TUCCI, Rogério Lauria. Teoria do direito processual penal. São Paulo: Revista dos Tribunais, 2002. p. 34.

35 MARINONI, Luiz Guilherme Teoria Geral do Processo. 4. ed. São Paulo: Revista dos Tribunais, 2010. p. 459-475.

36 CAPPELLETTI, Mauro; GARTH, Brian. Acesso à justiça. Trad. Ellen Gracie Northfleet. Porto Alegre: Sergio Fabris, 1988. p. 90-94. 
a preocupação fundamental é, cada vez mais, com a 'justiça social', isto é, com a busca de procedimentos que sejam conducentes à proteção das pessoas comuns. ${ }^{37}$

E mais, cresce a exigência de tutela jurisdicional dos direitos ou tutela diferenciada a cada posição do direito material, considerada a tutela jurisdicional como o

resultado final do exercício da jurisdição em favor de quem tem razão (e assim exclusivamente), isto é, em favor de quem está respaldado no plano do direito material. ${ }^{38}$

Pode-se então identificar, dentro dessa extensa lista de novas áreas ou ramos do direito processual (aplicado) na jurisdição não penal, grupos de processos com características comuns, identificáveis nesses agrupamentos, como forma ou critério metodológico de classificação interna dessas variantes.

Os autores brasileiros, a par de já identificarem a multiplicidade de áreas específicas do processo, relutam em formular ou reformular uma teoria (geral) que tenha caráter transversal, traspassando todas as novas áreas do direito processual. Por outro lado, autores, como o uruguaio Barrios de Angelis, propõe a ampliação da teoria geral para nela incluir o processo administrativo, trabalhista, aduaneiro e Ovalle Favela, mexicano, que mais amplamente subdivide as áreas em direito processual dispositivo (civil e mercantil), direito processual publicístico (penal, administrativo, familiar, constitucional e eleitoral) e direito processual social (trabalho, agrário e da seguridade social).

No Brasil Fredie Didier Jr. faz a mais expressiva proposição de criação de uma nova TGP em vista de mudanças como a força normativa da Constituição, a expansão e consagração dos Direitos Fundamentais e a expansão da jurisdição constitucional. Destaca outras razões mais expressivas como a ampliação da Teoria das Fontes e a adoção de técnicas como precedentes e cláusulas gerais que repercutem severamente sobre os ramos processuais. ${ }^{39}$

\section{CRItérIOS de CLAssificaçÃo dos processos na JURISDIÇÃo NÃo Penal}

Com a expansão da jurisdição civil ou, mais precisamente, com a expansão da jurisdição não penal somaram-se novos ramos à divisão clássica do direito processual, que inicialmente identificava, como ramos da Teoria Geral do Processo, apenas o processo civil e o processo do trabalho. A exclusão do direito processual penal do espectro de reflexão contido neste estudo preliminar se deve às razões apontadas no item n. 3 , que se interpõem como obstáculos à identidade das duas grandes áreas originais do processo (civil e penal). ${ }^{40}$

No Brasil o Direito Processual Civil serve de instrumento ao exercício da jurisdição civil, seja a exclusivamente privada (civil e comercial), como também a pública (constitucional, administrativa, tributária etc.). Essa amplitude se deve à opção do legislador, em não editar códigos de processo em áreas como, administrativa, tributária e outras.

Como forma classificatória dos demais ramos, optou-se por uma divisão que inclui três categorias: a) Processo para defesa dos Interesses Públicos ou do Patrimônio Público; b) Processo para defesa de interesses individuais privados e; c) Processos para defesa de interesses individuais privados de grupos especiais (Direito Processual de Grupos Sociais).

37 CAPPELLETTTI, Mauro; GARTH, Brian. Acesso à justiça. Trad. Ellen Gracie Northfleet. Porto Alegre: Sergio Fabris, 1988. p. 93.

38 YARSHELL, Flávio Luiz. Tutela jurisdicional. São Paulo: Atlas. 1999. p. 28. Em sentido similar vejam-se também: MARINONI, Luiz Guilherme. Técnica processual e tutela dos direitos. São Paulo: Revista dos Tribunais, 2004, p. 51-64; BEDAQUE. José Roberto dos Santos. Efetividade do processo e técnica processual. São Paulo: Malheiros, 2006. p. 72-102.

39 DIDIER JR., Fredie. Sobre a teoria geral do processo, essa desconhecida. 2. ed. Salvador: JusPodivm, 2013. p. 126-133.

40 Visto o Direito Processual Penal como o complexo de princípios e normas que regulam o exercício da jurisdição penal e a atividade de perseguição criminal exercidas pela Polícia Judiciária, não há incluí-lo na mesma categoria da jurisdição não penal. 
A utilidade dessas classificações pode ser didática, e não é raro que se duvide da autonomia de cada uma das possíveis divisões dos ramos do processo afeto à jurisdição não penal. Qualquer um desses obstáculos não invalida essa classificação, na medida em que se possam conjugar os grupos, por possuírem princípios próprios e comuns, mesmo quando não se encontre em tais disciplinas a autonomia legislativa ou ainda só exista uma incipiente construção doutrinária autônoma.

A seguir far-se-á uma descrição individuada de cada um desses agrupamentos.

\subsection{Processo para defesa dos interesses públicos ou do patrimônio público}

Como mencionado, o Direito Processual Civil serve de instrumento ao exercício da jurisdição civil em toda a sua extensão, seja para defesa do patrimônio do Estado, seja para defesa de interesses gerais, neles incluídos o ramo constitucional, o administrativo, o tributário etc. Contudo, tem-se nesse ramo do direito processual uma postura diferenciada para aplicação das regras processuais; orienta-se por princípios influenciados pelo direito público e a atuação das partes e do juiz sofre influência da natureza dos direitos litigados.

Incluem-se nessa categoria o Direito Processual Constitucional, o Direito Processual Administrativo (Direito Processual Público), o Direito Processual Tributário, o Direito Processual Eleitoral e o Direito Processual Ambiental. ${ }^{41}$

O critério ou os critérios que permitiram a reunião nessa área de disciplinas que podem ser consideradas tão díspares é o da proximidade delas ao interesse público, considerado em suas duas vertentes, como interesse público primário e interesse público secundário: o primeiro, como os interesses gerais e prevalentes de uma sociedade e os segundos, como o interesse específico dos sujeitos administrativos. Segundo esse critério, serviriam à defesa de interesses públicos primários o Direito Processual Constitucional, o Direito Processual Administrativo (Direito Processual Público) e o Direito Processual Tributário, o Direito Processual Eleitoral o e Direito Processual Ambiental, enquanto defenderiam interesses públicos secundários. Caracteriza-se pela quase completa indisponibilidade do direito material e processual, com pequenos espaços de transigibilidade regrada. ${ }^{42}$

Nesta área, têm aplicação ampla os princípios constitucionais da inafastabilidade, igualdade formal, proibição das provas ilícitas, devido processo, dever de fundamentar, publicidade e duplo grau. Esses ramos podem produzir decisões individuas, mas também de alcance geral (ultrapartes), como no Direito Processual Constitucional, visto também como um processo coletivo especial. ${ }^{43}$

\subsubsection{Direito Processual Constitucional}

Nelson Nery Jr. afirma que Direito Processual Constitucional e Direito Constitucional Processual não são ramos novos do direito processual, sendo ambos parte da jurisdição constitucional. Contudo, adverte que não se pode confundir o Direito Processual Constitucional, visto como a "reunião de princípios para o fim de regular a jurisdição constitucional," com Direito Constitucional Processual, este último como conjunto de normas de Direito Processual presentes na Constituição. ${ }^{44}$

41 Ainda, se possível fosse a conformação autônoma, seria aqui incluído o Direito Processual Concorrencial ou Econômico.

42 Ver, neste sentido: GUEDES, Jefferson Carús. Transigibilidade de interesses públicos: prevenção e abreviação de demandas da fazenda pública. In: GUEDES, Jefferson Carús; SOUZA, Luciane Moessa de (Coord.). Advocacia de estado: questões institucionais para a construção de um estado de justiça. Belo Horizonte: Fórum, 2009. p. 243-271.

43 ALMEIDA, Gregório Assagra de. Direito processual coletivo brasileiro: um novo ramo do direito processual. São Paulo: Saraiva, 2003. p. 157-262.

44 NERY JR., Nelson. Princípios do processo civil na Constituição. São Paulo: Revista dos Tribunais, 1992. p. 15-16. Diversa é a proposição classificatória de Eduardo Ferrer Mac-Gregor, amparada nos estudos de Héctor Fix-Zamudio, posta em dois diferentes trabalhos: El derecho procesal constitucional como disciplina jurídica autônoma, Anuario de Derecho Constitucional Latinoamericano, Anuario 2006, Tomo I, p. 353. FERRER MAC-GREGOR Eduardo. El derecho procesal constitucional como disciplina jurídica 
Se são efetivamente disciplinas distintas, fica claro que são dependentes entre si, e que se reportam no conjunto à Justiça Constitucional, mas afetas uma e outra, a procedimentos que podem ser absolutamente diversos; que podem ser privados em um e públicos em outro; que podem ser de repercussão geral em um e estritamente individual em outro.

Exemplos do Direito Processual Constitucional são os procedimentos especiais reunidos em duas categorias: a) a primeira referente às ações como o Mandado de Segurança, o Habeas Data, Mandado de Injunção, Ação Popular, Reclamação Constitucional e, b) a segunda, relacionada ao controle da constitucionalidade, tendo como instrumentos a Ação Direta de Inconstitucionalidade por ação e por omissão e a Ação Declaratória de Constitucionalidade (Lei n. 9.868/1999), a Arguição de Descumprimento de Preceito Fundamental (Lei n. 9.882/1999). Em síntese, a jurisdição constitucional.

Guiam-se, de modo amplo, pelos princípios constitucionais gerais do processo: o contraditório; a ampla defesa; o devido processo; o duplo grau de jurisdição; a igualdade; o dever de motivar decisões; a proibição da prova ilícita; a inafastabilidade do controle judicial; o juiz natural; a publicidade. As ações relacionadas ao controle da constitucionalidade possuem regras especiais que os atenuam ou diferenciam, assim como as especiais de competência, de legitimação especial, efeitos das decisões, de recursos e de prazos etc. associadas à necessidade de objetivação do processo e ao alcance que deve ter a decisão. Em muitos casos são procedimentos de legitimação especial e restrita a certos sujeitos processuais muito próprios.

\subsubsection{Direito Processual Administrativo (Direito Processual Público)}

\section{O Direito Processual Administrativo ou Direito Processual Público ${ }^{45}$ é a}

[...] parte do Direito Processual, [...] em que o Direito Público é o direito material envolvido, donde a redução do campo temático pela aposição do termo 'Público', de modo a estabelecer uma distinção em relação ao Direito Processual Civil. ${ }^{46}$

Para o efeito que se pretende com essa divisão, não está inserido nessa categoria todo o espectro de direitos considerados públicos, notadamente aqueles que se insiram em uma das demais classificações de direitos processuais de interesse público ou do patrimônio público. Também está excluído o Processo Administrativo em sua concepção não jurisdicional, passível de revisão pelo Poder Judiciário, como os demais exemplos citados.

O DPA orienta-se pelos princípios constitucionais do processo, com certa mitigação da igualdade e preservação de algumas prerrogativas em favor da Fazenda Pública e guiado pela busca da 'verdade real', com concessão de poderes instrutórios mais amplos ao juiz e aumento de seus poderes de direção do processo. Há, contudo, algumas matérias que envolvem Administração que ficam excluídas, por razões especiais, dessa força hegemônica que pode possuir a Administração em algumas situações processuais. ${ }^{47}$

Para o exercício desse direito utiliza o instrumento geral da jurisdição civil, o CPC, mas se complementa de regras processuais especiais como: Decreto-lei n. 3.365/1941, que regula a desapropriação; a Lei da

autônoma. In: ANUARIO de Derecho Constitucional Latinoamericano: 2006. Montevideo: Fundação Konrad-Adenauer, 2006. t. 2. p. 353-376. Disponível em: < http://www.juridicas.unam.mx/publica/librev/rev/dconstla/cont/2006.1/pr/pr18.pdf>. Acesso em: 26 fev. 2015. E Las garantias constitucionales del proceso y el Dedecho Constitucional Procesal, Panorámica del derecho procesal constitucionaly convencional, item IV, p. 133-137. FERRER MAC-GREGOR Eduardo. Las garantias constitucionales del proceso y el Derecho Constitucional Procesal. In: FERRER MAC-GREGOR Eduardo. Panorámica del derecho procesal constitucional y convencional. Barcelona: Marcial Pons, 2013. (Proceso Y Derecho) p. 133-137. Disponível em: <http://biblio.juridicas.unam.mx/libros/7/3384/10.pdf>. Acesso em: 26 fev. 2015.

45 A expressão poderá se criticada porquanto se argumente que todo o direito processual é público, embora aqui se refira ao direito material em disputa.

46 SUNDFELD, Carlos Ari. O direito processual e o direito administrativo. In: SUNDFELD, Carlos Ari; BUENO, Cássio Scarpinella. Direito processual público: a fazenda pública em juízo. São Paulo: Malheiros, 2000. p. 15-30. p. 17.

47 São exemplos as matérias Previdenciária, Assistencial ou Acidentária, quando tramitam em Juizados Especiais ou com competência delegada (acidentária), situações nas quais os privilégios processuais de entidades públicas são minorados ou desaparecem, nas quais se admite a possibilidade de transação regrada, são mitigados os meios recursais ou as ações impugnativas autônomas, entre outras alterações compensatórias. 
Ação Popular (Lei n. 4.717/1965); Lei da Ação Civil Pública (Lei n. 7.347/1985), leis sobre desapropriações, como a Lei Complementar n. 76/1993, lei sobre concessão e permissão da prestação de serviços públicos, Lei n. 8.987/1995, nova Lei do Mandado de Segurança (Lei n. 12.016/2009), dentre outras tantas. Entre os procedimentos mais poderosos de defesa estatal, integrantes do DPAD, está a Suspensão de Segurança (Lei n. 8.437/1992 e Medida Provisória n. 2.180-35/2001), que mitiga drasticamente os direitos processuais daqueles que litigam e obtém medidas urgentes contra a Administração. ${ }^{48}$

\subsubsection{Direito Processual Tributário}

O Direito Processual Tributário ou "o processo judicial tributário constitui a soma de princípio 'que vivificam o sentido e a função desempenhada pelos institutos jurídicos em nosso sistema jurídico', especificamente na relação fisco/contribuinte e contribuinte/fisco". ${ }^{49}$

Como regras especiais que dão conformação a esse ramo do direito processual se podem arrolar aquelas relacionadas à execução fiscal (Lei n. 6.830/1980), de um lado, e por outro, os procedimentos antiexacionais de defesa do contribuinte, defensivas, corretivas e reparadoras, como a ação anulatória de débito fiscal (art. 151, inc. V, do CTN). A nova Lei do Mandado de Segurança (Lei n. 12.016/2009) também é utilizada para fins defensivos contra atos da administração tributária.

Guia-se o DPT pelos princípios constitucionais processuais e por princípios gerais processuais cogentes, além de princípios específicos, como o princípio da proteção ao executado e da inexistência da execução sem o título. São exemplos de procedimentos Mandado de segurança individual e coletivo em matéria tributária, Ação de repetição e indébito tributário, Execução fiscal e embargos do executado, cautelares fiscais etc.

\subsubsection{Direito Processual Eleitoral}

O Direito Processual Eleitoral é o conjunto de normas processuais utilizadas em decorrência das demandas eleitorais e para a efetivação do direito material eleitoral, relacionado, portanto, com a eleição e com a candidatura ou a um mandato eleitoral público. Enquanto campo especial do processo, tem extensão menor que os demais ramos arrolados, embora preserve peculiaridades que se acentuam pela especialidade da justiça que o aplica, organizada desde o 1o Grau de jurisdição, em paralelo à justiça comum, seguida de Tribunais Regionais Eleitorais e do Tribunal Superior Eleitoral.

Configura-se o DPE por um conjunto de leis com regras materiais e processuais: Código Eleitoral (Lei n. 4.737/1965), Lei Orgânica dos Partidos Políticos (Lei 5.682/1971), Lei Complementar n. 64/1990, leis sobre eleições (Lei n. 9.100/1995, Lei n. 9.504/1997), regras que se valem apenas subsidiariamente do Código de Processo Civil.

Podem ser indicadas como regras especiais as que determinam como legitimados ativos os Partidos Políticos e Coligações, o Ministério Público Eleitoral e os próprios candidatos; como princípios, identificam-se a celeridade resultante da exiguidade de prazos, a ampliação dos poderes instrutórios do juiz, os poderes de requisição de provas (art. 5o, §3o, 4o e 5o, LC 64/1990) e certo poder normativo regulamentar atribuído à Justiça Eleitoral.

Dentre os procedimentos que dão contornos especiais a essa área do direito processual, está a Ação de Reclamação por Propaganda Irregular (Lei n. 9.054/1997), Ação de Investigação Judicial Eleitoral (LC n. 64/1990),

48 Este instrumento de defesa estatal, capaz de desequilibrar as relações processuais em que litigue o Estado (Entes federados e seus demais entes administrativos), permite que a defesa ultrapasse o plano exclusivamente jurídico, ingressando em questões econômicas, sociais e políticas, por meio incidental, interposto paralelamente a recursos, dirigido diretamente aos presidentes de tribunais (Tribunais de Justiça, Tribunais Regionais Federais, Superior Tribunal de Justiça e Supremo Tribunal Federal) e visando à obtenção de liminares suspensivas das ordens judiciais de órgãos inferiores.

49 CAIS, Cleide Previtalli. O processo tributário. 3. ed. São Paulo: Revista dos Tribunais, 2001. p. 223. 
Ação de Reclamação por Captação Irregular de Sufrágio (Lei n. 9.054/1997), Ação de Reclamação por Arrecadação e Gastos Ilícitos (Lei n. 9.054/1997, art. 30-A), Ação de Reclamação das Condutas Vedadas dos Agentes Públicos em Campanhas (Lei n. 9.054/1997, art. 30-A), Ação de Reclamação às Doações Irregulares aos Comitês Eleitorais (Lei n. 9.054/1997, art. 30-A), Ação de Impugnação de Mandato Eletivo (CF e LC n. 64/1990), Ação de Impugnação de Registro de Candidatura (LC n. 64/1990), Ação de Impugnação de Diplomação.

\subsubsection{Direito Processual Ambiental}

A CF de 1988 estabelece, no art. 170, inc. VI, a defesa do meio ambiente como princípio da ordem econômica, nele compreendido, o meio ambiente natural, o artificial, o cultural, o do trabalho e o meio ambiente genético.

A proteção processual dos direitos ambientais, veiculada pelo Direito Processual Ambiental se orienta por regras especiais de legitimação ativa e passiva, regras especiais recursais, amplitude do poder geral de cautela e a viabilidade mais larga da tutela de urgência e outras em face da ameaça ou lesão ao direito protegido e, ainda, regras especiais de competência. ${ }^{50}$ Não existe restrição a um instrumento processual para a defesa do meio ambiente, mas a ação civil pública se tem revelado dos meios mais adequados e eficazes para a defesa dos interesses e direitos relacionados a essa área.

Orienta-se o direito processual ambiental por princípios próprios, influenciados pelo direito material ambiental, com regras próprias de legitimação especial, princípio de proteção da verossimilhança como meio de prevenção da lesão, distribuição compensatória ou inversão do ônus da prova, princípio da prevenção. À exceção da ação civil pública (ACP), inexistem procedimentos especiais novos ou específicos para a defesa ambiental, estimulando a concessão de tutelas especiais na ACP ou em demandas que seguem o procedimento comum, considerado inadequado às peculiaridades do direito material. ${ }^{51}$ Dentre as técnicas processuais adequadas à defesa ambiental, são indicadas a antecipação da tutela, multa, execução direta, execução específica, ressarcimentos, compensações, indenizações.

\subsection{Processo para defesa de interesses individuais privados}

Essa é a área do direito processual que serviu de nascedouro das demais áreas do processo e é nela que se encontrarão as raízes, as marcas iniciais e os desdobramentos para as demais áreas processuais.

Caracteriza-se esse grande ramo pela disponibilidade dos interesses materiais nele litigados, que influenciam as leis de processo, trazendo a elas uma maior disponibilidade das regras, desde a demanda, o impulso oficial, a iniciativa probatória, a amplitude do objeto de prova, as regras e a extensão dos recursos.

Segue princípios constitucionais gerais do processo, tal como o contraditório; a ampla defesa; o devido processo; o duplo grau de jurisdição; a isonomia; o dever de motivar decisões; a proibição da prova ilícita; a inafastabilidade do controle judicial; o juiz natural; a publicidade, mas tem regras próprias que atenuam esses princípios ao permitir, por exemplo, a arbitragem privada, mitigando a regra da inafastabilidade da jurisdição. São ramos o Direito Processual Civil e o Direito Processual Comercial ou Empresarial. ${ }^{52}$

50 Ver a respeito obras específicas de FIORILLO, Celso Antonio Pacheco. Princípios do processo ambiental. São Paulo: Saraiva, 2004; e TESSLER, Luciane Gonçalves. Tutelas jurisdicionais do meio ambiente: tutela inibitória, tutela de remoção, tutela de ressarcimento na forma específica. São Paulo: Revista dos Tribunais, 2004.

51 Luciane Gonçalves Tessler, após apontar a inidoneidade do processo civil clássico para a tutela ambiental, destaca as técnicas efetivas e o processo coletivo como meios hábeis a essa espécie de direito material, indicados no próprio título da obra Tutelas jurisdicionais do meio ambiente: tutela inibitória, tutela de remoção, tutela de ressarcimento na forma específica, Parte II, itens 1-3. TESSLER, Luciane Gonçalves. Tutelas jurisdicionais do meio ambiente: tutela inibitória, tutela de remoção, tutela de ressarcimento na forma específica. São Paulo: Revista dos Tribunais, 2004. p. 155-382.

52 É possível que se classifique parte dessas áreas do processo como um "direito processual inquisitório”, em oposição ao "direito processual dispositivo”, considerando-se a cogência ou o caráter impositivo das regras processuais. 


\subsubsection{Direito Processual Civil}

O Direito Processual Civil restará ao fim deste estudo como o ramo do direito processual que reúne os princípios e as normas reguladoras da jurisdição civil em seu sentido estrito, dele excluídos todos os demais ramos da jurisdição não penal. Sua amplitude, seguido este raciocínio, é residual, mas incorpora as áreas que não adquiriram ainda 'autonomia' como o processo de sucessões, processo de parte da propriedade e posse de bens privados, o processo relacionado a contratos e obrigações e outros.

O DPC segue princípios constitucionais gerais do processo, com atenuação de certos princípios publicísticos, ora prestigiando a arbitragem privada, atenuando a regra da inafastabilidade da jurisdição, mas, principalmente, limitando a atividade do juiz à iniciativa das partes.

No plano dos princípios não constitucionais ou específicos, impõe-se maior rigor à exigência de inércia da jurisdição (art. $2^{\circ}$ do CPC) e ao princípio dispositivo, limitando a iniciativa probatória das partes (art. 132 do (PC), imposição de rigidez ao princípio da preclusão e da eventualidade e ampla imposição de penas sucumbenciais. Estão incluídos nessa área os procedimentos relacionados à posse e propriedade de bens, família, sucessões e a extensa área de obrigações e contratos privados não comerciais.

O novo CPC traz algumas mudanças importantes especialmente por mecanismos de coletivização de demandas individuais, "quando se deparar com diversas demandas individuais repetitivas", oficiar aos legitimados a propor a ação civil pública "para, se for o caso, promover a propositura da ação coletiva respectiva" que poderão servir a defesa desses interesses.

\subsubsection{Direito Processual Empresarial}

Por tradição brasileira recente, o Direito Processual Comercial se insere ou é absorvido por completo pelo Direito Processual Civil; contudo, na história do processo brasileiro, houve período de autonomia, como aquele ocorrido no Império, quando se editou o Código Comercial brasileiro (1850) e a regra processual que se lhe seguiu, o Regulamento $737 / 1850 . .^{33}$ No período republicano, quando se editaram códigos estaduais de processo, algumas dessas legislações locais eram dedicadas ao direito processual civil e ao direito processual comercial. ${ }^{54}$

Com a unificação do processo civil, pela edição do CPC de 1939, os procedimentos do processo comercial passaram a ser por ele regulados, com exclusão daqueles afetos a leis especiais, como o procedimento de falências, regulado desde 1945 pelo Dec. 7.661/1945, ${ }^{55}$ recentemente suplantado pela Lei n. 11.101/2005. Podem-se ainda arrolar como leis especiais, dentre outros, o Dec.-Lei 70/1966; Dec.-Lei 167/1967, sobre cobrança e execução de cédula rural; Dec. 911/1969; Lei 6.313/1975, sobre créditos à exportação e a Lei 6.840/80, sobre créditos comerciais.

Orienta-se, como o direito processual civil, pelos princípios constitucionais processuais e, no plano dos princípios não constitucionais, pelo rigor à exigência de inércia da jurisdição (art. $2^{\circ}$ do CPC) e do princípio

53 O Regulamento 737, de 25.11.1850, era norma processual específica do direito comercial, editada em seguida ao Código Comercial, mas teve, a partir de 1890, por força do Decreto 763, de 19.09.1890, do governo republicano, aplicação às causas cíveis. 54 São exemplos: Código do Processo Civil e Commercial do Estado do Rio Grande do Sul, Código do Processo Civil e Commercial do Estado do Maranhão, Código do Processo Civil e Commercial do Estado do Espírito Santo, Código do Processo Civil, Commercial, Penal e Orphanologico do Estado da Bahia, Código do Processo Civil e Commercial do Estado do Paraná, Código do Processo Civil e Commercial do Estado do Piaú, Código de Processo Civil e Commercial do Estado de Sergipe, Código do Processo Civil e Commercial do Estado do Ceará, Código do Processo Civil e Commercial do Estado do Rio Grande do Norte, Código do Processo Civil e Commercial do Estado do Pernambuco, Código do Processo Civil e Commercial do Distrito Federal, Código do Processo Civil e Commercial do Estado do São Paulo, Código do Processo Civil e Commercial do Estado do Espírito Santo, Código do Processo Civil e Commercial do Estado da Paraíba.

55 Por tradição, desde o Império e na República, as regras sobre quebras são autônomas com relação às demais regras processuais, podendo ser indicados como exemplos o Dec. 2.691/1860, Dec. 3.308/1865, Dec. 917/ 1890, Lei 2.024/1908. 
dispositivo, limitando a iniciativa probatória às partes (art. 132 do $\mathrm{CPC}$ ), imposição de rigidez ao princípio da preclusão, da eventualidade e da sucumbência.

O processo falimentar se reveste de características especiais, tal como a unicidade do juízo, e a preservação de interesses protegidos, com a hierarquia do quadro geral de credores, significativamente alterado pela Lei n. 11.101/2005, em que se privilegiam interesses privados com garantia, em detrimento de tributos e de interesses de trabalhadores, por exemplo.

Pode-se dizer que no Direito Processual Empresarial estão incluídos os procedimentos que servem de instrumento ao direito material societário e da empresa, bancário, dos títulos de crédito etc.

\subsection{Processos para defesa de interesses individuais especiais (Direito Processual de Grupos Sociais)}

Como fruto da divisão que foi anteriormente proposta, na qual a jurisdição civil ou não penal se divide em ramos de Processo para defesa dos Interesses Públicos ou do Patrimônio Público, Processo para defesa de interesses individuais privados, Processos para defesa de interesses individuais especiais (Direito Processual de Grupos Sociais), caracteriza-se este último pela presença de interesses privados diferenciados, amparados por regras materiais e, também, protegidos pelas regras processuais especiais.

O estudo que aproveite as reflexões da sociologia e da ciência política poderá apontar para critérios diferentes dos que adotamos neste estudo, principalmente se se considerar que certas áreas do direito e do processo estão relacionadas à afirmação de lutas sociais identificadas com o estado de bem-estar social, ao passo que outras (mais recentes) estão ligadas às lutas por legitimação de certos grupos sociais.

Orientam-se essas áreas do direito processual pelos princípios constitucionais processuais, pelos princípios processuais gerais e por princípios próprios, tal como o princípio da igualdade por compensação, o princípio do impulso oficial e o princípio distribuição compensatória ou da inversão do ônus da prova, às vezes presentes o princípio da flexibilidade da valoração das provas, os princípios da oralidade (imediatidade, concentração) e o princípio da especialização da justiça (juizados especiais e não de exceção).

Esse critério que segmenta os processos relacionados aos sujeitos especiais com interesses hoje protegidos tem suas próprias razões, que podem ser de ordem política ou ideológica. É possível que se aponte desconformidade entre as áreas, consideradas heterogêneas, pois nascidas e desenvolvidas em circunstâncias histórica e socialmente diversas.

\subsubsection{Direito Processual do Trabalho}

Das áreas mais bem estruturadas do Direito Processual Social e de nascimento mais distante, o Direito Processual do Trabalho "é o ramo do direito processual destinado à solução dos conflitos trabalhistas" ${ }^{56}$ fortalecido por uma legislação especial, a Consolidação das Leis do Trabalho, e por outras normas especiais de implicação processual e, ainda, por uma justiça especial própria, a Justiça do Trabalho.

Marcado por princípios próprios, o Direito Processual do Trabalho norteia-se pela proteção do trabalhador, pela normatividade das decisões coletivas, pela indisponibilidade do rito, pelo privilégio à conciliação, pela concentração de atos processuais e pelo incentivo à oralidade, pela irrecorribilidade das decisões interlocutórias, pela busca da verdade real etc.

Também se nota mitigação do princípio da demanda, quando se concede ao juiz a iniciativa na execução. e do princípio dispositivo, quando é ampliada a iniciativa probatória do juiz.

56 NASCIMENTO, Amauri Mascaro do. Curso de direito processual do trabalbo. 17. ed. São Paulo: Saraiva, 1997. p. 53. 
Como exemplo de procedimentos próprios, contém os dissídios individuais (ação individual: simples ou plúrimas), os dissídios coletivos de caráter normativo e força obrigatória (ação coletiva); o inquérito judicial para apuração de falta grave (ação declaratória de falta grave). Admitem-se também na Justiça do Trabalho as cautelares e certos procedimentos especiais (consignação em pagamento etc.) e possui execução que segue a CLT e subsidiariamente o CPC.

\subsubsection{Direito Processual Imobiliário Agrário e Urbano}

O Direito Processual Agrário, que tem em outros países ibero-americanos uma robusta conformação, no Brasil não teve o mesmo desenvolvimento, ainda que se identifique por suas peculiaridades e receba conceituação como aquele ramo que possui

objetivo, predominantemente público, com princípios e normas próprias, capazes de propiciar a solução rápida e sem excessos de formalismos, dos conflitos gerados no campo. ${ }^{57}$

É possível afirmar que a trajetória da construção dos direitos sociais, no plano legislativo, se desenvolve segundo um processo de afirmação constitucional, seguido por um processo de elaboração legal infraconstitucional para, depois, se estabelecer na via processual o instrumento para a sua afirmação e eficácia real ou material.

Alfredo Buzaid, citando Mauro Cappelletti, identificou a dificuldade de construção de um direito processual agrário no Brasil ao afirmar que:

na verdade o problema processual do direito agrário nada mais é do que uma manifestação de um problema mais vasto: o da autonomia jurídica deste ramo do direito. ${ }^{58}$

Pois a autonomia material precede à especialização processual.

A CF de 1988, art. 170, situa como princípio da ordem econômica a função social da propriedade, esta considerada essencial para o desenvolvimento da atividade agrícola, de criação de animais ou mesmo para as atividades extrativistas. Marcou a evolução da legislação agrária a edição do Estatuto da Terra (Lei n. 4.504/1964), ação discriminatória (Lei n. 6.383/1986), usucapião especial (Lei n. 6.969/1981), a regulamentação dos dispositivos constitucionais relativos à Reforma Agrária (Lei n. 8.629/1993). São tipicamente agrárias as demandas de cumprimento, de despejo, consignação, rescisão e indenização em contratos agrários, de preferência, de divisão, demarcação e extinção de condomínio agrário, usucapião especial e nunciação de obras rurais, além da desapropriação para fins de reforma agrária. Nota-se, contudo, uma expansão dos conflitos imobiliários do meio rural para o meio urbano, decorrente da migração de contingentes populacionais para as cidades. Com isso se pode hoje agrupar essas espécies de conflito em duas categorias imobiliárias similares: um Direito Processual Imobiliário Agrário, de luta pela terra, e outro Direito Processual Imobiliário Urbanos de luta pela moradia.

Esses ramos adotam, sem exceção, os princípios constitucionais processuais, tal como contraditório, ampla defesa, duplo grau, isonomia, publicidade etc. Quanto aos princípios gerais do processo: princípio dispositivo e da demanda, lealdade processual e boa-fé, e, também, princípios especiais ou próprios dentre os quais podem ser arrolados: princípios da simplificação e da oralidade, com identidade física e concentração de atos, princípio da gratuidade de justiça, princípio da indisponibilidade das regras e fixação da competência segundo o local dos bens litigados.

São exemplos de procedimentos dessa área o Usucapião especial agrário (Lei n. 6.969/1981), a Ação Discriminatória de Terras Públicas (Lei n. 6.383/1976) e as imissões possessórias agrárias, o usucapião especial

57 BORGES, Marcos Afonso. Princípios do direito processual: civil e agrário. Belém: CEJUP, 1991.p. 25-26.

58 BUZAID, Alfredo. Do processo agrário. In: BUZAID, Alfredo. Estudos e pareceres de direito processual civil. São Paulo: Revista dos Tribunais, 2002. p. 17-30. Essa atrofia pode ser decorrência, em parte, da inexistência de uma justiça especializada agrária, como em outras nações, mas também da desatenção estatal para o conflito social agrário e a fragilidade dos litigantes e de suas organizações associativas. 
urbano (Lei n. 10.257/2001), o usucapião especial coletivo (Lei n. 10.257/2001) e os mecanismos de cessão de uso de terras públicas ou mesmo os procedimentos de usucapião extrajudicial já criados ou projetados no novo CPC.

\subsubsection{Direito Processual Previdenciário e assistencial social}

O Direito Processual Previdenciário e Assistencial Social pode ser descrito como o conjunto de princípios e regras processuais que regulam os procedimentos com vistas à aquisição dos benefícios previdenciários e assistenciais $^{59}$ ou à parte do direito processual que tem como conteúdo material o litígio judicial pelos benefícios previdenciários e assistenciais. O benefício assistencial de prestação continuada previsto na Constituição Federal, art. 203, ${ }^{60}$ e regulamentado pela Lei Orgânica da Assistência Social (Lei n. 8.742/1993) ${ }^{61}$ não tem natureza previdenciária, sendo entretanto legitimado passivo da demanda o INSS, que gere o benefício para o Ministério do Desenvolvimento Social, justificando o tratamento processual conjunto.

De modo especial, após a edição da Lei dos Juizados Especiais Federais (Lei n. 10.259/2001), que se subsidia na Lei dos Juizados Especiais Cíveis e Criminais (Lei n. 9.099/1995) no que aquela não a contrariar, é desse sistema que se extrai o novo Direito Processual Previdenciário. Esse novo modelo se baseia na ampliação do acesso à justiça, em um modelo consensual, econômico e simplificado, oral e concentrado, informal e célere. Submetido ao limite de 60 salários mínimos, os pagamentos de condenação ou acordo nesses juizados não se vinculam ao pagamento por precatório, mas a pagamento direito de RPV (Requisições de Pequeno Valor).

Dificilmente se encontraria uma área ou áreas do direito processual que reunisse tal adequação aos Juizados Especiais Federais, como as ações para obtenção do benefício assistencial (CF, art. 203) e as ações para a obtenção dos benefícios previdenciários, decorrendo, neste caso, a identificação da subárea do processo com o próprio microssistema dos Juizados Especiais.

Mas se podem identificar critérios ou princípios próprios, tais como a celeridade, a simplicidade, a informalidade e a oralidade, além daqueles que se relacionam especificamente aos juizados especiais federais, tais como a ampliação dos poderes do juiz para deferir medidas urgentes (art. $4^{\circ}$ ), equivalente ao 'ativismo' processual, ausência de prazos diferenciados, isonomia com redução das prerrogativas da Fazenda Pública, fim do dogma da indisponibilidade do direito público, pagamento por ordem judicial, sem precatório, fim do reexame necessário e recurso somente sobre direito material, dirigido a turmas recursais etc.

Já somam muitas dezenas as obras sobre os Juizados Especiais Federais, mas, somente há pouco, surgiram obras dedicadas à doutrina processual da matéria previdenciária e assistencial social nesses juizados ou sobre a atuação da autarquia previdenciária (INSS). Nesse ramo especial, a doutrina pretende

a realização do ideal constitucional de um processo justo, isto é, um processo conduzido por uma atuação jurisdicional que leve em conta os particularismos da lide que se apresenta como carente de composição [...]. ${ }^{62}$

59 Para os efeitos restritos deste trabalho não foram incluídos os procedimentos ou ações fiscais ou antiexacionais relacionadas ao custeio da Previdência Social, sejam as originadas de contribuições sob gestão da Secretaria da Receita Previdenciária ou da Secretaria da Receita Federal, por se tratar puramente de Direito Processual Tributário.

60 "Art. 203. A assistência social será prestada a quem dela necessitar, independentemente de contribuição à seguridade social, e tem por objetivos: [...] V - a garantia de um salário mínimo de benefício mensal à pessoa portadora de deficiência e ao idoso que comprovem não possuir meios de prover à própria manutenção ou de tê-la provida por sua família, conforme dispuser a lei." BRASIL. Constituição (1988). Constituição da República Federativa do Brasil. Disponível em:<http://www.planalto.gov.br/ccivil_03/ constituicao/constituicao.htm>. Acesso em: 26 fev. 2015.

61 "Art. 20. O benefício de prestação continuada é a garantia de 1 (um) salário mínimo mensal à pessoa portadora de deficiência e ao idoso com 70 (setenta) anos ou mais e que comprovem não possuir meios de prover a própria manutenção e nem de tê-la provida por sua família." BRASIL. Lei n. 8.742, de 7 de dezembro de 1993. Disponível em: <http://www.planalto.gov.br/ccivil_03/leis/18742. htm>. Acesso em: 26 fev. 2015.

62 SAVARIS, José Antônio. Direito processual previdenciário. 4. ed. Curitiba: Juruá, 2012. p. 56. 
Assistemático, esse ramo se vem formando com base em regras especiais de competência, às vezes delegada à Justiça Comum dos Estados, exigência limitada de prévio requerimento administrativo à propositura de ações, relativização da indisponibilidade dos interesses públicos litigados e transigibilidade limitada, expansão das regras probatórias e adotando outras regras flexíveis, que admitem a fungibilidade entre alguns procedimentos para a obtenção de benefícios, relativa instabilidade da coisa julgada em alguns benefícios etc. ${ }^{63}$

A construção jurisprudencial é feita com caráter compensatório material e processual, como pode se ver na Súmula 47 TNU (Turma Nacional de Uniformização) dos Juizados Especiais Federais, exemplo de valoração de elementos não previstos expressamente na lei para a concessão de benefícios. ${ }^{64}$

\subsubsection{Direito Processual do Consumidor}

Há autores que consideram possível a existência de um sistema processual de defesa do consumidor, donde não haveria dificuldades de se extraírem regras próprias e caracterizadoras de um Direito Processual do Consumidor65 que se origina na Constituição Federal, art. 5o, inc. XXXII, onde se prevê que o Estado promoverá, na forma da lei, a defesa do consumidor e do art. 170, que estabelece como princípio da ordem econômica a defesa do consumidor (inc. V).

Conquanto à defesa processual do consumidor possa ser feita por todas as espécies de ações (art. 83 do CDC), essa lei especial, o Código de Defesa do Consumidor (Lei n. 8.078/1990), prevê regras processuais especiais e estabelece princípios que autorizam a sua conformação autônoma. Essa conformação autônoma se dá, em sua maior parte, pelo processo coletivo, pelas ações coletivas, cercado por todas as peculiaridades que esse sistema possui, mas não exclui o processo individual de consumo, que preserva singularidades, embora seja regido pelas normas gerais de processo (CPC) e por leis extravagantes.

Em qualquer das modalidades, haverá no processo a facilitação da defesa do consumidor e faculta-se ao juiz inverter do ônus da prova (art. $6^{\circ}$, inc. VIII), a tutela específica das obrigações (art. 84, $\int 6^{\circ}$, inc. VI), a responsabilização objetiva do fornecedor (art. 12) ou a possibilidade da execução individual in utilibus da condenação dada em ação coletiva e a ampliação dos poderes do juiz, que pode ser equiparado ao que se denomina 'ativismo' processual para a concessão de tutela de urgência (art. 84, \ $3^{\circ}$ ).

\subsubsection{Direito Processual do Nascituro, da Criança e Adolescente e dos Jovens}

Desde a Constituição Federal de 1988, ganhou contornos mais definidos os deveres do Estado na defesa de crianças e de adolescentes ${ }^{66}$ consolidados com a edição do Estatuto da Criança e do Adolescente, Lei n. $8.069 / 1990,{ }^{67}$ composto de largo rol de regras materiais penais e não penais. Novas leis, nos últimos anos, têm ampliado esse rol de grupos etários protegidos por leis especiais, como se vê com a criação do Estatuto da Juventude, Lei. n. 12.852/2013 ${ }^{68}$ e de outras normas.

63 SAVARIS, José Antônio. Direito processual previdenciário. 4. ed. Curitiba: Juruá, 2012. Caps. 2, 6, 7 e 10.

64 Súmula 47 - TNU "Uma vez reconhecida a incapacidade parcial para o trabalho, o juiz deve analisar as condições pessoais e sociais do segurado para a concessão de aposentadoria por invalidez. "BRASIL. Turma Nacional de Uniformização dos Juizados Especiais Federais. Súmula n. 47. Disponível em: <https://www2.jf.jus.br/phpdoc/virtus/sumula.php?nsul=47\&PHPSESSID=f2a 3nhiqcvr82dk0jbh67v1kt1>. Acesso em: 26 fev. 2015.

65 Exemplo é a obra recente de Adriano Perácio de Paula, com exame dos principais institutos processuais sob o enfoque dessa nova área do direito processual. PAULA, Adriano Perácio de. Direito processual do consumidor. Belo Horizonte: Del Rey, 2002.

66 Art. 227. É dever da família, da sociedade e do Estado assegurar à criança e ao adolescente, com absoluta prioridade, o direito à vida, à saúde, à alimentação, à educação, ao lazer, à profissionalização, à cultura, à dignidade, ao respeito, à liberdade e à convivência familiar e comunitária, além de colocá-los a salvo de toda forma de negligência, discriminação, exploração, violência, crueldade e opressão. BRASIL. Constituição (1988). Constituição da República Federativa do Brasil. Disponível em:<http://www.planalto.gov.br/ ccivil_03/constituicao/constituicao.htm>. Acesso em: 26 fev. 2015.

67 Para os efeitos do Estatuto da Criança e do Adolescente, são considerados adolescentes com idade entre 15 (quinze) e 18 (dezoito) anos, aplicando-se a estes inicialmente o ECA e, excepcionalmente o EJ.

68 Para os efeitos do Estatuto da Juventude, são consideradas jovens as pessoas com idade entre 15 (quinze) e 29 (vinte e nove) 
No campo processual, as regras destinadas a esses grupos sociais se ampliam e seguem a linha das leis especiais elaboradas nesse período, com inclusão de previsão de tutela específica, processo coletivo, regras especiais sobre competência e regras ampliadas de legitimidade, mudança dos efeitos dos recursos etc.

Rege-se por princípios constitucionais processuais, com destaque para a isonomia por compensação, que influencia os demais princípios processuais gerais e aqueles considerados especiais como a gratuidade de justiça e assistência jurídica, ausência de pagamento de despesas recursais (preparo), intimação pessoal do advogado e dos responsáveis, simplificação e celeridade (prazo para recursos é de 10 dias), preferência no julgamento de recursos, recursos com efeito apenas devolutivo e possibilidade de lesão (tutela de urgência), além das regras especiais de legitimação do Ministério Público, da Defensoria Pública, tanto para propor ações como para interpor recursos.

De modo similar à defesa processual do consumidor, a defesa de crianças e adolescentes pode ser feita por todas as espécies de ações (art. 212 do ECA), que também prevê regras processuais especiais e estabelece princípios que permitem estudo autônomo. O CPC tem aplicação subsidiária ao ECA $\left(\operatorname{art.} 212, \$ 1^{\circ}\right.$ ) e há previsão específica do cabimento da ação mandamental contra autoridade pública ou agente de pessoa jurídica, que lesem direito líquido e certo dos sujeitos protegidos pela lei. Também são utilizáveis quaisquer processos (comum ordinário ou sumário, executivo ou cautelar) ou procedimentos especiais (consignação, possessórias, alimentos etc.), com as influências principiológicas que o ECA introduziu.

Dentre as regras recursais, destaca-se a do inc. VII do art. 198 do ECA, que autoriza o juiz que rever sua decisão quando recorrida por apelação, proferindo nova, mantendo ou reformando o que decidira, antes de remetê-la à instância superior. O Estatuto da Juventude prevê a adoção de medidas com vista à proteção do direito de igualdade por meio de programas que permitam o estímulo à cidadania e o acesso à Justiça (EJ, art. 18 , inc. I).

Outra inovação quanto aos direitos de grupos etários é a possibilidade de concessão de alimentos ao nascituro, ditos alimentos gravídicos, previstos na Lei n. 11.804/2008, pois destinados à gestante. Com previsão de concessão de medida urgente, após 'cognição sumária', baseada em indícios, redução de prazo para resposta para 5 dias e a possibilidade de conversão desses alimentos em pensão para o caso de nascimento com vida. Aplicam-se também a essa ação de alimentos aquelas diferenciações da Lei n. 5.478/1968 (Lei de Alimentos).

Não se pode deixar de mencionar também a possibilidade das ações ou do processo coletivo para a defesa de interesses não individuais desses grupos sociais, para o qual estão legitimados o Ministério Público, a Defensoria Pública, os entes federativos e as associações criadas para a defesa de interesses de crianças e de adolescentes ${ }^{69}$ e de jovens.

\subsubsection{Direito Processual dos Idosos}

A Constituição Federal de $1988^{70}$ não foi com os idosos tão minudente como na defesa de crianças e de adolescentes, contudo o Estatuto do Idoso (Lei n. 10.741/2003), a par de criar regras especiais de proteção, ratificar a garantia a direitos, medidas de proteção e atendimento aos idosos, preocupou-se especificamente com o acesso à Justiça (Título V, arts. 69 a 92).

anos de idade $\left(\operatorname{art} .1^{\circ}, \int 1^{\circ}\right)$.

69 Ver sobre o tema a obra SILVA, Moacir Motta da; VERONESE, Josiane Rose Petry. A tutela jurisdicional dos direitos da criança e do adolescente. São Paulo: LTr, 1998.

70 Art. 230. A família, a sociedade e o Estado têm o dever de amparar as pessoas idosas, assegurando sua participação na comunidade, defendendo sua dignidade e bem-estar e garantindo-lhes o direito à vida. BRASIL. Constituição (1988). Constituição da República Federativa do Brasil. Disponível em: <http://www.planalto.gov.br/ccivil_03/constituicao/constituicao.htm>. Acesso em: 26 fev. 2015. 
O Estatuto do Idoso principia a formação de um microssistema de Direito Processual dos Idosos, com regras e princípios próprios, tais como: a) a aplicação subsidiária do procedimento sumário do CPC, arts. 275 a 281 (art. 69, EI); b) tratamento judicial prioritário no trâmite de qualquer processo em qualquer instância (art. 71 do EI e arts. 1211-A, 1211-B e 1211-C do CPC) 71. c) a intervenção para proteção de interesses ou direitos coletivos de idosos (art. 74 do EI); d) a participação do Ministério Público como custos legis ou como substituto em ações especiais (art. 74 do EI) e legitimidade para a execução (art 87 do EI); e) cabimento de ações especiais (art. 82 do EI); f) cabimento da tutela específica (art. 83 do EI); g) possibilidade de concessão de efeito suspensivo a recurso judicial (art. 85 do EI) dentre outras. ${ }^{72}$

Esse conjunto de regras, associado a outras contidas na legislação esparsa, pode ser compreendido como o Direito Processual dos Idosos, com tendência à expansão, quando associado ao processo previdenciário e assistencial do qual, por certo, pode ser distinguido, conquanto o universo de idosos se defina pela idade; enquanto o previdenciário, pela natureza retributiva da obrigação previdenciária e o assistencial, pela presença das condições de carência e obrigação estatal de proteção social.

\subsubsection{Direito Processual dos Acidentados e de Pessoas com Deficiência}

Improvável que se possa, com segurança científica, estabelecer uma área do direito processual que reúna o Direito Processual Acidentário e ações para defesa de interesses de portadores de deficiências (Lei n. 7.853/1989), mas as peculiaridades de ambos impedem a inclusão nas subáreas anteriormente listadas.

Direito Processual Acidentário. De um lado está a ação acidentária, prevista na Lei n. 6.376/1976, com suas peculiaridades processuais, com a alteração de competência que se desloca para o local do fato, na Justiça Estadual, ainda que a legitimidade passiva seja do INSS, pela presença do Ministério Público como fiscal da lei, com a concessão de jus postulandi à parte ou ao representante não advogado, princípio da 'verdade real', mitigação dos princípios dispositivo e da demanda, celeridade e simplificação pela adoção do procedimento sumário, princípio da gratuidade de justiça, valorização da conciliação e transigibilidade dos interesses. Essa norma é o marco para a definição de um direito processual acidentário.

Direito Processual das Pessoas com Deficiência. De outra parte, os processos regrados pela Lei n. 7.853/1989, relacionada às pessoas com deficiência objetiva o acesso à justiça para a obtenção de meios adequados de desenvolvimento da pessoa com deficiência, seja pela educação especial, pela adaptação arquitetônica, pela adaptação do ambiente de trabalho ou ambiente urbano, de modo a permitir sua atuação social, profissional e seu lazer.

Todos os meios processuais existentes são aptos às demandas das pessoas com deficiência, seja para a proteção de direitos à não discriminação, à educação, à saúde, ao trabalho, à acessibilidade aos benefícios previdenciários e assistenciais ou outros. Há peculiaridades processuais, como a necessidade de reexame necessário, não produzindo efeitos a sentença, senão após exame do $2^{\circ}$ grau, nas ações civis públicas, que se concluir pela carência ou improcedência (art. $4^{\circ}, \int 1^{\circ}$, Lei n. 7.853/1989) e a necessidade de participação do Ministério

71 "Art. 1.211-A. Os procedimentos judiciais em que figure como parte ou interessado pessoa com idade igual ou superior a 60 (sessenta) anos, ou portadora de doença grave, terão prioridade de tramitação em todas as instâncias. Art. 1.211-B. A pessoa interessada na obtenção do benefício, juntando prova de sua condição, deverá requerê-lo à autoridade judiciária competente para decidir o feito, que determinará ao cartório do juízo as providências a serem cumpridas. $\int 1^{\circ}$ Deferida a prioridade, os autos receberão identificação própria que evidencie o regime de tramitação prioritária. Art. 1.211-C. Concedida a prioridade, essa não cessará com a morte do beneficiado, estendendo-se em favor do cônjuge supérstite, companheiro ou companheira, em união estável." BRASIL. Lei n. 12.008, de 29 de julho de 2009. Disponível em: <http://www.planalto.gov.br/ccivil_03/_Ato2007-2010/2009/Lei/L12008. htm>. Acesso em: 26 fev. 2015.

72 GODINHO, Robson Renault. A proteção processual dos direitos dos idosos: Ministério Público, tutela dos direitos individuais e coletivos e acesso à Justiça. 2. ed. Rio de Janeiro: Lumen Juris, 2010. p. 68, identifica esse conjunto de regras como microssistema sem, contudo, tratá-lo como 'tutela diferenciada'. 
Público nas ações onde se litiguem interesses de pessoas com deficiência. ${ }^{73} \mathrm{~A}$ jurisprudência, de outra parte, tem ampliado a visão compensatória do processo e do direito em relação às pessoas com deficiência.

O Estatuto da Juventude prevê políticas de segurança pública voltadas para os jovens e dentre essas a "promoção do efetivo acesso dos jovens com deficiência à justiça em igualdade de condições com as demais pessoas, inclusive mediante a provisão de adaptações processuais adequadas a sua idade" (art. 38, inc. VI), acesso à Defensoria Pública (art. 38, inc. V), entre outros.

Outro ponto que contribui ao estudo em tópico próprio é a edição de um Estatuto do Portador de Deficiência, como regra legal matriz que reunirá o direito material e processual para a defesa de interesses desses sujeitos especiais, em fase de processo legislativo.

\subsubsection{Direito Processual da Família}

As regras especiais afetas ao Direito de Família não são novas no Brasil. Especialmente a partir da Lei de Alimentos, que reuniu dispositivos relacionados ao direito material e ao direito processual se pode elencar outras que nitidamente trouxeram especificidades relacionadas ao processo que envolve tal matéria. ${ }^{74}$

Há inúmeras peculiaridades procedimentais dispersas pela legislação codificada ou esparsa, como as alterações de competência, alterações de legitimação para a ação, alterações de prazo para a resposta do demandado, amplitude de matérias na contestação na e reconvenção, aceitando-se em alguns procedimentos a duplicidade (divórcio), imposição de fases de conciliação, ampliação de poderes do juiz. A ação de alimentos é o exemplo dessa demarcação procedimental, pois já na década de 1960 prevê que

o juiz, para instrução da causa ou na execução da sentença ou do acordo, poderá tomar todas as providências necessárias para seu esclarecimento ou para o cumprimento do julgado ou do acordo, inclusive a decretação de prisão do devedor até 60 (sessenta) dias, ${ }^{75}$

Expressando evidente exacerbação de poderes do juiz ao permitir-lhe aplos poderes instrutórios e medidas coercitivas para o atendimento da decisão.

O novo CPC vai mais longe, ao criar no Capítulo X, com título "das ações de família”, situado dentre os procedimentos especiais de jurisdição contenciosa um conjunto de regras gerais com o fim de afetar as ações relacionadas ao Direito de Família, tais como divórcio, separação, reconhecimento e extinção de união estável, guarda, visitação e filiação, além das ações de alimentos e de interesse de crianças e adolescentes. A nova técnica procedimental estabelece um princípio geral, de busca de solução consensual e para isso uma inverte o procedimento nessas demandas de família, transpondo a citação do réu e a respectiva e eventual contestação para um momento posterior ao da tentativa de conciliação, posicionada logo após o recebimento da inicial.

73 Art. $3^{\circ}$ As ações civis públicas destinadas à proteção de interesses coletivos ou difusos das pessoas portadoras de deficiência poderão ser propostas pelo Ministério Público, pela União, Estados, Municípios e Distrito Federal; por associação constituída há mais de 1 (um) ano, nos termos da lei civil, autarquia, empresa pública, fundação ou sociedade de economia mista que inclua, entre suas finalidades institucionais, a proteção das pessoas portadoras de deficiência. $\int 1^{\circ}$ Para instruir a inicial, o interessado poderá requerer às autoridades competentes as certidões e informações que julgar necessárias. $\int 2^{\circ}$ As certidões e informações a que se refere o parágrafo anterior deverão ser fornecidas dentro de 15 (quinze) dias da entrega, sob recibo, dos respectivos requerimentos, e só poderão se utilizadas para a instrução da ação civil. $\int 3^{\circ}$ Somente nos casos em que o interesse público, devidamente justificado, impuser sigilo, poderá ser negada certidão ou informação. $\int 4^{\circ}$ Ocorrendo a hipótese do parágrafo anterior, a ação poderá ser proposta desacompanhada das certidões ou informações negadas, cabendo ao juiz, após apreciar os motivos do indeferimento, e, salvo quando se tratar de razão de segurança nacional, requisitar umas e outras; feita a requisição, o processo correrá em segredo de justiça, que cessará com o trânsito em julgado da sentença. $\int 5^{\circ}$ Fica facultado aos demais legitimados ativos habilitarem-se como litisconsortes nas ações propostas por qualquer deles. $\int 6^{\circ} \mathrm{Em}$ caso de desistência ou abandono da ação, qualquer dos colegitimados pode assumir a titularidade ativa. BRASIL. Lei n. 7.853, de 24 de outubro de 1989. Disponível em: <http://www.planalto.gov.br/ ccivil_03/leis/17853.htm>. Acesso em: 26 fev. 2015.

74 São exemplos a ação de alimentos, ação de divórcio, a ação de alimentos gravídicos etc.

75 Lei de Alimentos, Lei n. 5.478/1968, art. 19. BRASIL. Lei n. 5.478, de 25 de julho de 1968. Disponível em: < http://www.planalto.gov.br/ccivil_03/leis/15478.htm>. Acesso em: 26 fev. 2015. 
São destacáveis o princípio da busca da consensualidade, com utilização da conciliação e da mediação judicial ou extrajudicial, flexibilização e inversão procedimental, a admissão de auxiliares multidisciplinares ao juízo e profissionais externos para a busca de composição, inversão procedimental sem citação inicial, chamamento a juízo, sem conhecimento da inicial, para a audiência de tentativa de composição, fragmentação da audiência, quando necessário, pleno acesso do réu aos documentos e inicial, se desejar antes da audiência de composição, imposição de defesa técnica por advogado ou defensor público.

\subsubsection{Direito Processual dos Negros, Pardos, Indígenas e outros grupos étnicos}

Outra área que apresenta expansão, com corte étnico ou racial está associada a grupos que se autodenominam negros, pardos e indígenas. Considera-se negro a aquele que se autodeclara preto, pardo ou denominação análoga, no quesito cor e raça das pesquisas do IBGE (Estatuto da Igualdade Racial, Lei n. 12.288/2010, art. $1^{\circ}$, par. ún., inc. IV). São considerados pardos e com equivalência em direitos aos negros aqueles que assim se declaram (Estatuto da Igualdade Racial, Lei n. 12.288/2010, art. ${ }^{\circ}$, par. ún., inc. IV). A preservação de suas características culturais pode ser identificada na própria Constituição, ao definir que o ensino fundamental regular será ministrado a todos em língua portuguesa, mas assegurando às comunidades indígenas também a utilização de suas línguas maternas (art. 210, $\$ 2^{\circ}$ ). Assim também a defesa de suas manifestações culturais $\left(\operatorname{art} .215, \sqrt{ } 1^{\circ}\right.$ ); a vedação a sua remoção de suas terras (art. 231, $\int 5^{\circ}$ ). Os quilombolas que são grupos étnicos formados principalmente por descendentes de populações negras, que se autodefinem como tal a partir das relações com a terra, o parentesco, o território, a ancestralidade, as tradições e práticas culturais próprias. ${ }^{76}$

Embora não se encontrem até este momento normas processuais específicas de diferenciação desses grupos, o Estatuto da Igualdade Racial, Lei n. 12.288/2010, prevê art. 55 que "para a apreciação judicial das lesões e das ameaças de lesão aos interesses da população negra decorrentes de situações de desigualdade étnica, recorrer-se-á, entre outros instrumentos, à ação civil pública". O Estatuto da Juventude prevê a adoção de medidas com vista à proteção por meio de programas que permitam o estímulo à cidadania e o acesso à Justiça em igualdade de direitos aos jovens de todas as raças e etnias (EJ, art. 18, inc. I).

Quanto aos indígenas se pode destacar regra constitucional de proteção que autolegitima o indígena e colegitima as comunidades e associações na representação processual desses grupos, ${ }^{77}$ deixando ao Ministério Público como custos legis.

Segundo o Estatuto do Índio (Lei n. 6.001/1973), é dever dos entes federativos a proteção das comunidades indígenas e a preservação dos seus direitos, por meio da assistência aos índios e às comunidades indígenas (art. $2^{\circ}$, inc. II), assim como a garantia ao pleno exercício dos direitos civis e políticos que em face da legislação lhes couberem (art. $2^{\circ}$, inc. X).

A lei que institui a Fundação Nacional do Índio- FUNAI, Lei n. 5.371/1967, prevê dentre as suas finalidades respeito à pessoa do índio e as instituições e comunidades tribais; (art. $1^{\circ}$, inc. I, 'a'), garantia à posse permanente das terras que habitam e ao usufruto exclusivo dos recursos naturais e de todas as utilidades nela existentes (art. $1^{\circ}$, inc. I, 'b '), preservação do equilíbrio biológico e cultural do índio, no seu contacto com

76 O Decreto n. 4.887/2003 prevê no "Art. $2^{\circ}$ Consideram-se remanescentes das comunidades dos quilombos, para os fins deste Decreto, os grupos étnico-raciais, segundo critérios de autoatribuição, com trajetória histórica própria, dotados de relações territoriais específicas, com presunção de ancestralidade negra relacionada com a resistência à opressão histórica sofrida.” BRASIL. Decreto n. 4.887, de 20 de novembro de 2003. Disponível em: <http://www.planalto.gov.br/ccivil_03/decreto/2003/d4887.htm>. Acesso em: 26 fev. 2015.

77 "Art. 232. Os índios, suas comunidades e organizações são partes legítimas para ingressar em juízo em defesa de seus direitos e interesses, intervindo o Ministério Público em todos os atos do processo." Contudo, esse dispositivo constitucional deve ser interpretado limitadamente nos casos de indígena não integrado e sem acesso aos usos e costumes da comunhão nacional. BRASIL. Constituição (1988). Constituição da República Federativa do Brasil. Disponível em: < http://www.planalto.gov.br/ccivil_03/constituicao/constituicao.htm>. Acesso em: 26 fev. 2015 
a sociedade nacional; (art. $1^{\circ}$, inc. I, 'c'), promover a prestação da assistência médico-sanitária aos índios; (art. $1^{\circ}$, inc. IV), promover a educação de base apropriada do índio visando à sua progressiva integração na sociedade nacional (art. $1^{\circ}$, inc. V). Para isso todos os meios processuais são válidos, sejam as ações constitucionais, os procedimentos especiais individuais e coletivos e o CPC.

Deve ser destacado o procedimento para o reconhecimento Usucapião Especial Indígena, previsto no art. 33 do Estatuto do Índio, Lei n. 6.001/1973, norma material com contornos próprios para a aquisição da propriedade imobiliária. ${ }^{78}$

\section{Do acesso à Justiça ao Direito Processual de Grupos Sociais}

Sob este tópico, ainda que sumariamente, é importante definir o que são o acesso à justiça, a socialização da justiça e o processo justo e, também, o Direito Social e o Direito Processual de Grupos Sociais, como tentativa de traçar uma linha comum nessa tendência evolutiva das leis materiais e processuais brasileiras.

\subsection{Acesso à Justiça, socialização do processo e processo justo}

Para que se concretize a acessibilidade da justiça, nas proposições originais de Mauro Cappelletti e Briant Garth, destacam-se a redução dos custos do processo, a busca de isonomia substancial das partes no processo, a assistência jurídica e judicial e a gratuidade de justiça. Numa visão que se afirmava transcendente, esses autores propunham ainda a criação de métodos não contenciosos ou não adversariais de solução dos conflitos, o aproveitamento de auxiliares leigos e a criação de procedimentos e juízos especiais simplificados. ${ }^{79}$ Pode-se concluir que a legislação esparsa brasileira da segunda metade do século XX, e mais acentuadamente das décadas de 80 e 90, teve essa finalidade, esse objetivo.

A doutrina italiana, pelas pesquisas de Mauro Cappelletti e, também, de Vittorio Denti, expostas na obra Processo civile e giustizia sociale, caracterizava, na década de 70, a socialização do processo pela introdução de técnicas como a simplificação, a gratuidade de justiça, a participação de juízes laicos, a ampliação dos poderes e a participação do juiz como árbitro de conflitos sociais e a tendência para a inquisitoriedade dos processos com finalidade social. ${ }^{80}$ Sob esse enfoque, o fenômeno identificado pela doutrina brasileira como socialização do processo pode também ser descrito como um conjunto de modificações legislativas que operaram uma lenta transformação das regras processuais, no qual se pode destacar como principal a tutela coletiva ou de grupos e onde está também incluída a noção de acesso individual à justiça, introduzida precedentemente ao processo coletivo. Não têm portanto, esses dois eventos ou fenômenos, uma identidade completa, embora os autores brasileiros acima citados acreditassem que uma das ondas finais do acesso se expressaria pela introdução de processo coletivo ou de grupos.

Já a concepção de procedimento justo tem origem no direito anglo-saxão, na cláusula do due process of law que foi transmudada de garantia formal e de garantia substancial em garantia constitucional escrita em nações de leis escritas. ${ }^{81}$ Relaciona-se o procedimento justo com a preocupação do tempo de duração raz̧oável do processo,

78 Art. 33. O índio, integrado ou não, que ocupe como próprio, por dez anos consecutivos, trecho de terra inferior a cinquenta hectares, adquirir-lhe-á a propriedade plena. Parágrafo único. O disposto neste artigo não se aplica às terras do domínio da União, ocupadas por grupos tribais, às áreas reservadas de que trata esta Lei, nem às terras de propriedade coletiva de grupo tribal. BRASIL. Lei n. 6.001, de 19 de dezembro de 1973. Disponível em: <http://www.planalto.gov.br/ccivil_03/leis/16001.htm>. Acesso em: 26 fev. 2015.

79 CAPPELLETTT, Mauro; GARTH, Brian. Acesso à justiça. Trad. Ellen Gracie Northfleet. Porto Alegre: Sergio Fabris, 1988.

80 DENTI, Vittorio. Processo civile e giustizia sociale. Milano: Edizioni di Comunità, 1971. p. 53-72.

81 COMOGLIO, Luigi Paolo. Garanzie costituzionale e "giusto processo" (modelli aconfronto). Revista de Processo, São Paulo, v. 23, n. 90, p. 95-150, abr./jun. 1998.p. 105. 
que objetiva o resultado útil desse procedimento aos litigantes. ${ }^{82}$ Identifica-se a justeza do procedimento não apenas pela simples "oferta [numérica e variada] de instrumentos processuais", mas que esses instrumentos sejam suficientes a produzir o resultado desejável do processo, que seja um fim útil e concreto, ou, no dizer de Arruda Alvim, que a eles corresponda a "efetiva eficácia," 83 sem considerar a transversalidade contida na proposta de acesso, que considera a fragilidade subjetiva do litigante.

\subsection{Direito Social e Direito Processual de Grupos Sociais}

Direito Social, por sua vez, é conceito que foi formulado originalmente no Brasil na proposição de Cesarino Junior ${ }^{84}$ como:

a ciência dos princípios e leis geralmente imperativas, cujo objetivo imediato é, tendo em vista o bem comum, auxiliar as pessoas físicas, dependentes do produto do seu trabalho para a subsistência própria e de suas famílias, a satisfazerem as necessidades vitais e a ter acesso à propriedade privada[...]

Vinculada a fase de formação dos direitos trabalhistas.

Mas a expressão social, que qualifica o direito, tem uso corrente desde o século XIX, como oposição ao liberalismo ou ao capitalismo. Essa concepção tem evoluído e hoje se considera que

el derecho social abriga inicialmente la defensa de los más pobres, de los desposeídos, de quienes se distinguen em la sociedad por tener menos condiciones materiales, por no tener las mismas oportunidades para su desarrollo. Son los débiles econômica o socialmente marginados y excluídos. El derecho social anida y tutela, como derecho positivo, los derechos de los campesinos (derecho agrario), de los indigentes (derecho asistencial), de los grupos más vulnerables (derecho de seguridad social) y de los trabajadores hombres y mujeres, niños, jóvenes, adultos y ancianos (derecho do trabajo); disciplinas que se van conformando para despúes cobrar autonomía científica según la evolución de cada una y conforme a la propia evolución jurídica en general. ${ }^{85}$

Em uma concepção atual, o direito social é visto como o direito das desigualdades, direito de privilégios, para a proteção de categorias ou grupos de indivíduos, útil inclusive às políticas administrativas de governo, caracterizado como direito contraditório e polêmico, em contraposição a outros direitos, enfeixados em um conjunto de normas provisórias e flexivelmente integradas. ${ }^{86}$

O Direito Processual de Grupos Sociais surge como direito instrumental ao direito material social, ou à parte do direito processual que tem por fim fazer efetivo o direito material social (trabalhista, agrário, da seguridade, dos idosos, dos adolescentes, dos jovens, das pessoas com deficiência, dos consumidores, dos negros e indígenas) e, embora constituído ou identificado em época posterior, introduz e consolida as mesmas técnicas compensatórias, deixando de lado a proposição liberal de igualdade entre as partes (no processo). Constitui-se como o conjunto de regras gerais e regras especiais, assim como de princípios especiais e peculiares para que se alcance pelo processo o objeto do direito material social, sob a forma também protetiva e compensatória em favor da parte frágil da relação processual. Segundo José Ovalle Favela

las normas procesales destinadas a la aplicación del derecho social, para ser eficaces, deben estar inspiradas en el mismo principio de igualdad por compensación o, como tambien se llama, principio de justicia social; deben tener como punto de partida las desigualdades reales de las partes, para tratar de

82 TUCCI, José Rogério Cruz. e. Tempo e processo: uma análise empírica das repercussões do tempo na fenomenologia processual (civil e penal). São Paulo, Revista dos Tribunais, 1997. p. 63-87.

83 ALVIM NETTO, José Manuel de Arruda. Manual de direito processual civil. 15. ed. São Paulo: Revista dos Tribunais, 2012. p. 92-93.

84 CESARINO JUNIOR, A. F.; CARDONE, Marly. Direito social. 2. ed. São Paulo: LTr , 1993. v. 1.p. 36-37.

85 KURCZYN VILLALOBOS, Patrícia; REYNOSO CASTILLO, Carlos; SÁNCHEZ-CASTAÑEDA, Alfredo. La justicia laboral: administración e impartición. Ciudad del Mexico: UNAM, 2005. p. 15.

86 MACEDO JUNIOR, Ronaldo Porto. Ação civil pública, o direito social e os princípios. In: YARSHELL, Flávio Luiz; MORAIS, Maurício Zanoide de (Org.). Estudos em homenagem à professora Ada Pellegrini Grinover. São Paulo: DPJ, 2005. p. 290-299. p. 294-295. 
otorgarles una verdadera igualdad de oportunidades en el proceso, atribuyendo la carga de la prueba de los hechos discutidos, a la parte que esté en mejores condiciones reales de aportar los medios de prueba, e incrementando las faculdades de dirección del juzgador; deben procurar la mayor rapidez y sensillez en los procedimientos, pues sus dilaciones y complicaciones normalmente son en perjuicio de la parte trabajadora o campesina. 87

Em vista da heterogeneidade das categorias ou espécies procedimentais incluídas nessa divisão, poder-se-ia cindi-la em duas sendo: a) a primeira - do Direito Processual Social original, nascido das respostas do Estado do Bem-Estar Social, na qual se incluiriam o Direito Processual do Trabalho, Direito Processual Previdenciário e Assistencial Social e Direito Processual Agrário (e Fundiário Urbano); b) a segunda - do Direito Processual de Grupos Sociais, mais recente ou tardio, na qual se incluiriam Direito Processual do Consumidor; Direito Processual da Infância e Adolescência; Direito Processual dos Idosos; Direito Processual Acidentário e de Deficientes, estes vinculados à denominada "luta por reconhecimento" social.

Esta nova ordenação dos agrupamentos de áreas processuais identifica-se com novas disputas sociais, associadas a novos direitos econômicos, sociais e culturais, próprios de sociedades pós-contemporâneas, marcadas pelo pluralismo, pela diversidade e pela multiculturalidade. Para Charles Taylor, o multiculturalismo está ligado

[...] a outra exigência que estamos agora a considerar [...] de que todos reconheçam o valor igual das diferentes culturas; que as deixemos, não só sobreviver, mas também admitamos o seu mérito. ${ }^{88}$

Se, embora distintas as culturas, tenham elas igual valor, podem assim se reconhecer e como tal devem ser tratadas. Já a luta por reconhecimento é conceito desenvolvido por Axel Honneth, em obra sobre Teoria Crítica ${ }^{89}$ Essa tendência de luta por espaço social também foi notada em exame da evolução histórica da forma de decidir dos juízes, diante dos novos ordenamentos e dos conflitos de interesse, revestidos de tendências em conflito recíproco e mutuamente excludentes. ${ }^{90}$

Nesse sentido, o Direito Processual de Grupos Sociais é o ramo processual que tenta identificar similaridades nesse variado conjunto de normas dispersas e assimétricas de proteção e diferenciação processual correspondente à proteção e compensação de categorias, grupos, estamentos, classes etc. Sob uma breve análise história, seu desenvolvimento corresponde à uma etapa de ascensão política desses grupos e de luta por direitos sociais, econômicos e políticos em sociedades multiculturais, desiguais e complexas. ${ }^{91}$

\section{3. 'Ativismo' processual e Direito Processual de Grupos Sociais}

Como citado acima, essa área processual constitui-se como o conjunto de regras gerais e regras especiais, assim como de princípios especiais e peculiares para que se alcance pelo processo o objeto do direito material social, sob a forma também protetiva e compensatória em favor da parte frágil da relação processual. Esse viés, por si, estimula um comportamento processual do juiz que avança em dois sentidos: primeiro com um afrouxamento de certas regras processuais, com a flexibilização e atenuações de exigências, redução de 'deveres' ou de ônus processuais e; segundo, com uma relativa ampliação dos poderes dirigentes e instrutórios do juiz que ultrapassa linhas definidas na busca de determinadas provas, ao modo que em litígios de interesse geral ou de interesse público.

87 OVALLE FAVELA, José. Teoría general del proceso. 6. ed. Ciudad del Mexico: Oxford, 2005. p. 62-63.

88 TAYLOR, Charles. Multiculturalismo: examinando a política de reconhecimento. Trad. Marta Machado. Lisboa: Instituto Piaget, 1998. p. 84.

89 HONNETH, Axel. Luta por reconbecimento: a gramática moral dos conflitos sociais. São Paulo: 34, 2003: a gramática moral dos conflitos sociais, no qual propõe uma análise dos conflitos sociais com superação do antecedente "déficit sociológico", no qual o viés de imperatividade econômica desconsidera a ação social dos indivíduos.

90 WAMBIER, Teresa Arruda Alvim. Controle das decisões judiciais por meio de recursos de estrito direito e de ação rescisória. São Paulo: Revista dos Tribunais, 2001. p. 22-25.

91 GUEDES, Jefferson Carús. Igualdade e desigualdade: introdução conceitual, normativa e histórica dos princípios. São Paulo: Revista dos Tribunais, 2014. Itens 7.5-7.7, p. 202-214, onde são classificadas as desigualdades simples e unidimensionais, assim como as complexas e multidimensionais. 
Tais alterações são examinadas neste estudo somente quanto aos efeitos processuais, mas não se exclui outras alterações que ultrapassem o processo e alcancem o mérito, nas quais a consideração de aspectos próprios das partes, tal como a vulnerabilidade, possam resultar em efeitos materiais. Exemplo disso são as causas biopsicossociais como critérios supralegais para a concessão de benefícios previdenciários pelos Tribunais. ${ }^{92}$

Exemplos dessa atuação podem ser vistos nos juizados especiais.

\section{Juizados Especiais como microssistema legal de Direito Processual de Grupos Sociais}

Importante, portanto, que se examine isoladamente também o microssistema dos juizados especiais, visto por duas vertentes essenciais: os Juizados Especiais Cíveis e Criminais (estaduais) da Lei n. 9.099/1995, os Juizados Especiais Federais da Lei n. 10.259/2001 e os Juizados Especiais da Fazenda Pública da Lei n. $12.153 / 2009$.

Os Juizados Especiais Cíveis (Estaduais), criados pela Lei n. 9.099/1995, surgiram mais de uma década após a edição da Lei 7.244/1984, que instituíra os pioneiros Juizados de Pequenas Causas, voltados à solução de demandas de pequeno valor econômico, exclusivamente no âmbito cível e limitada ao processo de conhecimento.

A Constituição Federal de 1988 constitucionalizou a matéria e ampliou a atuação dos juizados especiais, prevendo a criação dos Juizados Criminais, competentes para a apreciação, julgamento e execução dos "crimes de menor potencial ofensivo", art. 98, inc. I, da CF/1988"93.

Permite-se a participação popular (conciliadores e juízes leigos), com utilização da oralidade, com simplificação, prestigiando a primeira instância que colhe a prova (identidade física), com imediatidade e com concentração de grande parte dos atos na audiência. A concessão de jus postulandi às partes permite que a parte litigue sem assistência técnica, excluindo o advogado nas causas de até 20 salários mínimos (SM), excepcionado a interposição de recurso, que precisa de advogado. A Emenda Constitucional n. 19/1998 permitiu a aplicação dos juizados especiais à Justiça Federal, Lei n. 10.259/2001 (art. $1^{\circ}$ da Lei n. 10.259, de 12-07-2001), que criou um sistema parcialmente comunicante entre a Lei dos Juizados Especiais Cíveis e Criminais (Lei n. 9.099/1995) e a Lei dos Juizados Especiais Federais.

Com competência para processar, conciliar e julgar causas da Justiça Federal até o valor de 60 SM, inclui na sua competência, ${ }^{94}$ por exemplo, as ações promovidas contra o INSS, autarquia federal encarregada de pagar mensalmente os benefícios previdenciários e assistenciais a mais de 30 milhões de pessoas. Trouxeram inovações importantes em relação às restrições das prerrogativas da Fazenda Pública, com expressa possibilidade de deferimento de medidas urgentes para evitar dano de difícil reparação (art. $4^{\circ}$ ), simplificação dos atos de comunicação processual (art. $8^{\circ}$ ), possibilidade de composição e de transação (art. 10), cumpri-

92 BRASIL. Superior Tribunal de Justiça. Recurso Especial. REsp n. 965.597/PE. Quinta Turma. Recorrente: Instituto Nacional do Seguro Social. Recorrido: José Nascimento da Silva. Rel. Min. Napoleão Nunes Maia Filho. Brasília, 23 de agosto de 2007. Disponível em: <http://stj.jusbrasil.com.br/jurisprudencia/8880888/recurso-especial-resp-965597-pe-2007-0151676-9/relatorioe-voto-13983772>. Acesso em: 26 fev. 2015.

93 São evidentes as inovações trazidas pela lei dos juizados especiais criminais, a iniciar pelo rompimento de dogmas históricos, notadamente no direito processual penal, como o que se refere à 'conciliação' nas demandas criminais, com a introdução da disponibilidade parcial da 'ação penal', antes considerada obrigatória. BRASIL. Constituição (1988). Constituição da República Federativa do Brasil. Disponível em: <http://www.planalto.gov.br/ccivil_03/constituicao/constituicao.htm>. Acesso em: 26 fev. 2015.

94 São incompetentes esses JEFs para conhecer de mandado de segurança, ação de desapropriação, de divisão e demarcação, populares, execuções fiscais, demandas sobre improbidade administrativa e as demandas sobre direitos ou interesses difusos, coletivos ou individuais homogêneos; ações sobre bens imóveis da União, autarquias e fundações públicas federais; anulação ou cancelamento de ato administrativo federal, salvo o de natureza previdenciária e os de lançamento fiscal; ações relativas à sanção disciplinar a servidor público federal $\left(\operatorname{art} .3^{\circ}, \int 1^{\circ}\right)$. 
mento de obrigação que não seja de dar, será efetuado mediante ofício do juiz à autoridade (art. 14) e de obrigação de dar em 30 dias (art. 15), participação de juízes leigos e de conciliadores (art. 16). Quanto aos recursos, desaparecem os prazos diferenciados, inclusive para a prática de outros atos processuais (art. $9^{\circ}$ ) e irrecorribilidade em separado das decisões interlocutórias (art. $5^{\circ}$ ) e da sentença homologatória (art. 42, Lei n. 9.099/1995), e não haverá reexame necessário (art. 12, \ ún.), com o recurso da sentença dirigido a turmas recursais (art. 16).

Todas essas medidas simplificadoras e de igualação das partes ampliam o acesso à Justiça aos litigantes que demandam contra a Administração federal, estadual, distrital e municipal, notadamente dos integrantes de grupos sociais que buscam benefícios previdenciários e assistenciais, demandas de saúde, por serviços hospitalares, tratamentos ou medicamentos, mas também outras disputas individuais que os juizados admitam em sua competência Há inúmeros exemplos estabilizados por Enunciados do Fórum Nacional dos Juizados Especiais Federais.

O juiz que atua nesses juizados especiais não decide contra as provas, mas diligencia e busca as provas e os elementos necessários à decisão, de modo mais 'ativo' que nas demandas privadas em que não há esses interesses socialmente protegidos. ${ }^{95}$ Esse juiz, ainda quando a Administração não contesta o pedido nos JEF, se vale de defesa já depositada em juízo, a conhece sem que a parte ré a junte e decide o mérito. ${ }^{96}$ Esse juiz aplica sanções que podem ultrapassar limite de competência dos próprios JEF.97

\section{Direito Processual Coletivo (Constitucional, Trabalho, Consumidor, Ambiental, Tributário) como técnica de acesso ao Direito Processual de Grupos Sociais}

O Direito Processual Coletivo pode ser conceituado como o ramo do direito processual constitucional-social, com regras próprias de jurisdição coletiva dos interesses supraindividuais coletivos e difusos, capaz de interferir positivamente na realidade social; ${ }^{98}$ destinando-se à obtenção da tutela jurisdicional coletiva,

95 FÓRUM NACIONAL DE JUIZADOS ESPECIAIS. Enunciado 101. A Turma Recursal tem poder para complementar os atos de instrução já realizadospelo juiz do Juizado Especial Federal, de forma a evitar a anulação da sentença. Disponível em: <http:// www.cjf.jus.br/cjf/Lista\%20completa\%20dos\%20enunciados\%20do\%20Fonajef.pdf>. Acesso em: 26 fev. 2006: a Turma Recursal tem poder para complementar os atos de instrução já realizados pelo juiz do Juizado Especial Federal, de forma a evitar a anulação da sentença. FÓRUM NACIONAL DE JUIZADOS ESPECIAIS. Enunciado 102. Convencendo-se da necessidade de produção de prova documental complementar, a Turma Recursal produzirá ou determinará que seja produzida, sem retorno doprocesso para o juiz do Juizado Especial Federal. Disponível em: <http://www.cjf.jus.br/cjf/Lista $\% 20$ completa $\% 20$ dos $\% 20$ enunciados $\% 20$ do $\% 20$ Fonajef.pdf $>$. Acesso em: 26 fev. 2006: convencendo-se da necessidade de produção de prova documental complementar, a Turma Recursal produzirá ou determinará que seja produzida, sem retorno do processo para o juiz do Juizado Especial Federal. FÓRUM NACIONAL DE JUIZADOS ESPECIAIS. Enunciado 103. Sempre que julgar indispensável, a Turma Recursal, sem anular a sentença, baixará o processo em diligências para fins de produção de prova testemunhal, pericial o elaboração de cálculos. Disponível em: < http://www.cjf.jus.br/cjf/Lista $\% 20$ completa $\% 20$ dos $\% 20$ enunciados $\% 20$ do $\% 20$ Fonajef.pdf $>$. Acesso em: 26 fev. 2006 : sempre que julgar indispensável, a Turma Recursal, sem anular a sentença, baixará o processo em diligências para fins de produção de prova testemunhal, pericial ou elaboração de cálculos.

96 FÓRUM NACIONAL DE JUIZADOS ESPECIAIS. Enunciado 2. Excetuando-se os embargos de declaração, cujo prazo de oposição é de cinco dias, os prazos recursais contra decisões de primeiro grau no âmbito dos Juizados Especiais Federais são sempre de dez dias, independentemente da natureza da decisão recorrida. Disponível em: <http://www.cjf.jus.br/cjf/Lista\%20 completa $\% 20 \mathrm{dos} \% 20$ enunciados $\% 20 \mathrm{do} \% 20$ Fonajef.pdf>. Acesso em: 26 fev. 2006: nos casos de julgamentos de procedência de matérias repetitivas, é recomendável a utilização de contestações depositadas na Secretaria, a fim de possibilitar a imediata prolação de sentença de mérito.

97 FÓRUM NACIONAL DE JUIZADOS ESPECIAIS. Enunciado 65. Não cabe a prévia limitação do valor da multa coercitiva (astreintes), que tambémnão se sujeita ao limite de alçada dos Juizados Especiais Federais, ficando sempre assegurada a possibilidade de reavaliação do montante final a ser exigido na formado parágrafo $6^{\circ}$. do artigo 461 do CPC. Disponível em: < http://www.cjf.jus. $\mathrm{br} / \mathrm{cjf} /$ Lista $\% 20$ completa $\% 20$ dos $\% 20$ enunciados $\% 20 \mathrm{do} \% 20$ Fonajef.pdf $>$. Acesso em: 26 fev. 2006: não cabe a prévia limitação do valor da multa coercitiva (astreintes), que também não se sujeita ao limite de alçada dos Juizados Especiais Federais, ficando sempre assegurada a possibilidade de reavaliação do montante final a ser exigido na forma do parágrafo $6^{\circ}$ do artigo 461 do CPC.

98 ALMEIDA, Gregório Assagra de. Direito processual coletivo brasileiro: um novo ramo do direito processual. São Paulo: Saraiva, 
considerada como a capacidade de alteração das situações pretéritas à intervenção jurisdicional que objetivava a proteção aos interesses ou direitos transindividuais ameaçados ou violados. ${ }^{99}$

Conforme mencionado anteriormente, o Direito Processual de Grupos Sociais pode conter microssistemas associados ao conteúdo material da pretensão veiculada pela ação, tal como o direito do trabalho ou da seguridade social. Essa divisão não é válida quando se pensa no processo ou na tutela coletiva, capaz de abrigar diversas pretensões materiais, sejam elas de direito tributário, constitucional ou outras, sem vinculação exata e exclusiva com o que se denomina Direito Processual Social original ou com o Direito Processual de Grupos Sociais secundário ou tardio. Assim, mais adequado interpretar o processo coletivo como uma técnica para a pacificação social, também transversal (que traspassa várias espécies de direito material), útil a certas modalidades de interesses materiais que, por conveniências a essas modalidades pode atender com uniformidade e vantagens o direito posto em litígio. As vantagens do processo coletivo são reiteradamente apontadas: celeridade, uniformidade, economia processual etc.

Orienta-se pelos princípios constitucionais processuais tais como o devido processo e ampla defesa, princípio da proporcionalidade, princípio da supremacia da Constituição, princípio da não desistibilidade da ação de controle de constitucionalidade. O processo coletivo se orienta ainda por regras e princípios próprios tal como legitimação especial, presença do Ministério Público, transigibilidade regrada pela possibilidade de ajustamento de conduta, princípio da disponibilidade motivada, princípio da efetividade máxima das decisões e do máximo benefício e o princípio da obrigatoriedade da execução coletiva.

Gregório Assagra de Almeida propõe a divisão do Direito Processual Coletivo brasileiro em duas grandes áreas, uma relacionada ao processo coletivo especial, com conteúdo propriamente constitucional (ação de inconstitucionalidade por ação e por omissão, ação direta de constitucionalidade e arguição de descumprimento de preceito fundamental) e, outra, relacionada ao processo coletivo comum, no qual se incluem a ação civil pública, o mandado de segurança, o mandado de injunção, a ação popular, o dissídio coletivo trabalhista, a impugnação de mandato eletivo e a ação direta interventiva. ${ }^{100}$

São exemplos, a Ação Popular (art. 5, LXXIII da CF e Lei n. 4.717/1965), a Ação Civil Pública (art. 129, III e Lei n. 7.347/1985), o mandado de segurança coletivo (art. 5², LXIX e LXX), ADI (art. 102, I, a), o Estatuto da Criança e do Adolescente (Lei n. 8.069/1990), o Código de Defesa do Consumidor (Lei n. 8.078/1990), o Estatuto do Idoso (Lei n. 10.741/2003), dentre outras normas especiais.

Os juizados especiais, de outra parte, são vistos como uma técnica especial e individual de pacificação social, mas incompatível com o processo coletivo, merecendo exame isolado.

\section{O novo CPC e o Direito Processual de Grupos Socials}

O novo CPC traz algumas mudanças importantes especialmente quanto a mecanismos de coletivização de demandas individuais, como: a) quando o juiz "se deparar com diversas demandas individuais repetitivas", oficiar aos legitimados a propor a ação civil pública "para, se for o caso, promover a propositura da ação coletiva respectiva"; b1) no incidente de conversão de ação individual em coletiva, quando tenha alcance coletivo, em razão da tutela de bem jurídico difuso ou coletivo, assim entendidos aqueles definidos pelo art. 81, parágrafo único, incisos I e II, do CDC e cuja ofensa afete, a um só tempo, as esferas jurídicas do indivíduo e da coletividade; b2) quando "tenha por objetivo a solução de conflito de interesse relativo

2003. p. 147. Item n. 1.1, p. 22 e item n. 4.4.3, p. 147. Barbosa Moreira é cético na capacidade de o direito processual interferir na realidade social, 8 a Série, p. 16.

99 VIGLIAR, José Marcelo Menezes. Tutela jurisdicional coletiva. 3. ed. São Paulo: Atlas, 2001. p. 34.

100 ALMEIDA, Gregório Assagra de. Direito processual coletivo brasileiro: um novo ramo do direito processual. São Paulo: Saraiva, 2003. 
a uma mesma relação jurídica plurilateral, cuja solução, pela sua natureza ou por disposição de lei, deva ser necessariamente uniforme, assegurando-se tratamento isonômico para todos os membros do grupo"; c) no incidente de assunção de competência "quando ocorrer relevante questão de direito a respeito da qual seja conveniente a prevenção ou a composição de divergência entre câmaras ou turmas do tribunal” no "julgamento de recurso, da remessa necessária ou de causa de competência originária envolver relevante questão de direito, com grande repercussão social, sem repetição em diversos processos."

Em todos esses casos, pretende-se proteger grupos identificáveis por situações jurídicas específicas ou mais precisamente direitos individuais homogêneos e, indiretamente, também, a grupos sociais, no sentido indicado no título deste artigo.

No que se refere a Grupos Sociais, sejam vulneráveis ou não, o projeto do CPC traz poucas referências específicas. Uma delas, considerada uma inovação, se refere às ações de família, acima referidas, que terão a partir de então, novo tratamento.

\section{REFERÊNCIAS}

ALMEIDA, Gregório Assagra de. Direito processual coletivo brasileiro: um novo ramo do direito processual. São Paulo: Saraiva, 2003.

ALVES, Cleber Francisco. Justiça para todos: assistência jurídica gratuita nos Estados Unidos, na França e no Brasil. Rio de Janeiro: Lumen Juris, 2006.

ALVIM NETTO, José Manuel de Arruda. Anotações sobre as perplexidades e os caminhos do processo civil contemporâneo. Revista de Processo, São Paulo, v. 16, n. 64, p. 217-246, out./dez. 1991.

ALVIM NETTTO, José Manuel de Arruda. Manual de direito processual civil. 15. ed. São Paulo: Revista dos Tribunais, 2012.

BEDAQUE. José Roberto dos Santos. Efetividade do processo e técnica processual. São Paulo: Malheiros 2006.

BORGES, Marcos Afonso. Princípios do direito processual: civil e agrário. Belém: CEJUP, 1991.

BRASIL. Constituição (1988). Constituição da República Federativa do Brasil. Disponível em: < http://www.planalto.gov.br/ccivil_03/constituicao/constituicao.htm>. Acesso em: 26 fev. 2015.

BRASIL. Decreto n. 4.887, de 20 de novembro de 2003. Disponível em: < http:/ /www.planalto.gov.br/ccivil_03/ decreto/2003/d4887.htm>. Acesso em: 26 fev. 2015

BRASIL. Lei n. 5.478, de 25 de julho de 1968. Disponível em: <http://www.planalto.gov.br/ccivil_03/leis/ 15478.htm>. Acesso em: 26 fev. 2015.

BRASIL. Lei n. 6.001, de 19 de dezembro de 1973. Disponível em: < http://www.planalto.gov.br/ccivil_03/ leis/16001.htm>. Acesso em: 26 fev. 2015.

BRASIL. Lei n. 7.853, de 24 de outubro de 1989. Disponível em: <http://www.planalto.gov.br/ccivil_03/leis/ 17853.htm>. Acesso em: 26 fev. 2015.

BRASIL. Lei n. 8.742, de 7 de dezembro de 1993. Disponível em: <http://www.planalto.gov.br/ccivil_03/leis/ 18742.htm>. Acesso em: 26 fev. 2015.

BRASIL. Lei n. 12.008, de 29 de julho de 2009. Disponível em: <http://www.planalto.gov.br/ccivil_03/_ Ato2007-2010/2009/Lei/L12008.htm>. Acesso em: 26 fev. 2015. 
BRASIL. Superior Tribunal de Justiça. Recurso Especial. REsp n. 965.597/PE. Quinta Turma. Recorrente: Instituto Nacional do Seguro Social. Recorrido: José Nascimento da Silva. Rel. Min. Napoleão Nunes Maia Filho. Brasília, 23 de agosto de 2007. Disponível em: <http:/ / stj.jusbrasil.com.br/jurisprudencia/8880888/ recurso-especial-resp-965597-pe-2007-0151676-9/relatorio-e-voto-13983772>. Acesso em: 26 fev. 2015.

BRASIL. Turma Nacional de Uniformização dos Juizados Especiais Federais. Súmula n. 47. Disponível em: <https://www2.jf.jus.br/phpdoc/virtus/sumula.php?nsul=47\&PHPSESSID=f2a3nhiqcvr82dk0jbh67v1 kt1>. Acesso em: 26 fev. 2015

BUZAID, Alfredo. Do processo agrário. In: BUZAID, Alfredo. Estudos e pareceres de direito processual civil. São Paulo: Revista dos Tribunais, 2002. p. 17-30.

CAIS, Cleide Previtalli. O processo tributário. 3. ed. São Paulo: Revista dos Tribunais, 2001.

CAMBI, Eduardo. Neoconstitucionalismo e neoprocessualismo: direitos fundamentais, políticas públicas e protagonismo judiciário. São Paulo: Revista dos Tribunais, 2010.

CAPPELLETTTI, Mauro; GARTH, Brian. Acesso à justiça. Trad. Ellen Gracie Northfleet. Porto Alegre: Sergio Fabris, 1988.

CESARINO JUNIOR, A. F.; CARDONE, Marly. Direito social. 2. ed. São Paulo: LTr, 1993. v. 1.

CINTRA, Antonio Carlos Araújo; GRINOVER, Ada Pellegrini; DINAMARCO, Cândido Rangel. Teoria geral do processo. 20. ed. São Paulo: Malheiros, 2004.

COMOGLIO, Luigi Paolo. Garanzie costituzionale e "giusto processo" (modelli aconfronto). Revista de Processo, São Paulo, v. 23, n. 90, p. 95-150, abr./jun. 1998.

Couture, Eduardo J. Fundamentos de derecho procesal civil. 3. ed. Buenos Aires: Depalma, 1976.

DENTI, Vittorio. Processo civile e giustizia sociale. Milano: Edizioni di Comunità, 1971.

DIDIER JR., Fredie. Os três modelos de direito processual: inquisitivo, dispositivo e cooperativo. In: LEITE, George Salomão; SARLET, Ingo Wolfgang; CARBONELL, Miguel (Coord.). Direitos, deveres e garantias fundamentais. Salvador: JusPodivm, 2011. p. 427-439.

DIDIER JR., Fredie. Sobre a teoria geral do processo, essa desconbecida. 2. ed. Salvador: JusPodivm, 2013.

DINAMARCO, Cândido Rangel. Instituições de direito processual civil. São Paulo: Malheiros, 2001. v. 1.

DINAMARCO, Cândido Rangel. Instrumentalidade do processo. 3. ed. São Paulo: Malheiros, 1993.

FERRER MAC-GREGOR, Eduardo. El derecho procesal constitucional como disciplina jurídica autônoma. In: ANUARIO de Derecho Constitucional Latinoamericano: 2006. Montevideo: Fundação KonradAdenauer, 2006. t. 2. p. 353-376. Disponível em: < http://www.juridicas.unam.mx/publica/librev/rev/ dconstla/cont/2006.1/pr/pr18.pdf>. Acesso em: 26 fev. 2015.

FERRER MAC-GREGOR, Eduardo. Las garantias constitucionales del proceso y el Derecho Constitucional Procesal. In: FERRER MAC-GREGOR, Eduardo. Panorámica del derecho procesal constitucionaly convencional. Barcelona: Marcial Pons, 2013. (Proceso Y Derecho) p. 133-137. Disponível em: <http://biblio.juridicas. unam.mx/libros/7/3384/10.pdf>. Acesso em: 26 fev. 2015.

FIORILLO, Celso Antonio Pacheco. Princípios do processo ambiental. São Paulo: Saraiva, 2004.

FÓRUM NACIONAL DE JUIZADOS ESPECIAIS. Enunciado 2. Excetuando-se os embargos de declaração, cujo prazo de oposição é de cinco dias, os prazos recursais contra decisões de primeiro grau no âmbito dos Juizados Especiais Federais são sempre de dez dias, independentemente da natureza da decisão recorrida. Disponível em: < http://www.cjf.jus.br/cjf/Lista $\% 20$ completa $\% 20$ dos $\% 20$ enunciados $\% 20$ do $\% 20$ Fonajef.pdf>. Acesso em: 30 mar. 2015. 
FÓRUM NACIONAL DE JUIZADOS ESPECIAIS. Enunciado 65. Não cabe a prévia limitação do valor da multa coercitiva (astreintes), que tambémnão se sujeita ao limite de alçada dos Juizados Especiais Federais, ficando sempre assegurada a possibilidade de reavaliação do montante final a ser exigido na formado parágrafo $6^{\circ}$. do artigo 461 do CPC. Disponível em: <http://www.cjf.jus.br/cjf/Lista $\% 20$ completa $\% 20$ dos $\% 20$ enunciados $\% 20$ do\%20Fonajef.pdf>. Acesso em: 30 mar. 2015.

FÓRUM NACIONAL DE JUIZADOS ESPECIAIS. Enunciado 101. A Turma Recursal tem poder para complementar os atos de instrução já realizados pelo juiz do Juizado Especial Federal, de forma a evitar a anulação da sentença. Disponível em: <http://www.cjf.jus.br/cjf/Lista $\% 20$ completa $\% 20$ dos\%20enunciados\%20do\%20Fonajef.pdf>. Acesso em: 30 mar. 2015.

FÓRUM NACIONAL DE JUIZADOS ESPECIAIS. Enunciado 102. Convencendo-se da necessidade de produção de prova documental complementar, a Turma Recursal produzirá ou determinará que seja produzida, sem retorno do processo para o juiz do Juizado Especial Federal. Disponível em: < http:/ /www.cjf. jus.br/cjf/Lista $\% 20$ completa $\% 20$ dos $\% 20$ enunciados $\% 20$ do $\% 20$ Fonajef.pdf>. Acesso em: 30 mar. 2015.

FÓRUM NACIONAL DE JUIZADOS ESPECIAIS. Enunciado 103. Sempre que julgar indispensável, a Turma Recursal, sem anular a sentença, baixará o processo em diligências para fins de produção de prova testemunhal, pericial o elaboração de cálculos. Disponível em: <http://www.cjf.jus.br/cjf/Lista\%20completa $\% 20$ dos $\% 20$ enunciados $\% 20$ do\%20Fonajef.pdf $>$. Acesso em: 30 mar. 2015

GODINHO, Robson Renault. A proteção processual dos direitos dos idosos: Ministério Público, tutela dos direitos individuais e coletivos e acesso à Justiça. 2. ed. Rio de Janeiro: Lumen Juris, 2010.

GONZALEZ GARCIA, Jesús María. La proliferación de processos civiles. Madrid: McGranw-Hill, 1996.

GRINOVER, Ada Pellegrini. Deformalização do processo e deformalização das controvérsias. In: GRINOVER, Ada Pellegrini. Novas tendências do direito processual. 2. ed. Rio de Janeiro: Forense Universitária, 1990. p. 175-204.

GUEDES, Jefferson Carús. Direito processual social atual: entre o ativismo judicial e o garantismo processual. In: DIDIER JR., Fredie et al (Coord). 'Ativismo' judicial e o garantismo processual. Salvador: JusPodivm, 2013. p. 351-382.

GUEDES, Jefferson Carús. Direito processual social atual: entre o ativismo judicial e o garantismo processual. Revista Brasileira de Direito Processual, v. 82, p. 45-79, abr./jun. 2013.

GUEDES, Jefferson Carús. Igualdade e desigualdade: introdução conceitual, normativa e histórica dos princípios. São Paulo: Revista dos Tribunais, 2014.

GUEDES, Jefferson Carús. Transigibilidade de interesses públicos: prevenção e abreviação de demandas da fazenda pública. In: GUEDES, Jefferson Carús; SOUZA, Luciane Moessa de (Coord.). Advocacia de estado: questões institucionais para a construção de um estado de justiça. Belo Horizonte: Fórum, 2009. p. 243-271.

HONNETH, Axel. Luta por reconhecimento: a gramática moral dos conflitos sociais. São Paulo: 34, 2003.

KURCZYN VILLALOBOS, Patrícia; REYNOSO CASTILLO, Carlos; SÁNCHEZ-CASTAÑEDA, Alfredo. La justicia laboral: administración e impartición. Ciudad del Mexico: UNAM, 2005.

LACERDA, Galeno. Eficácia da prestação jurisdicional no atendimento às demandas sociais. In: CARVALHO, Carlos Henquie (Colab.). Uma vida dedicada ao direito: homenagem a Carlos Henrique de Carvalho: o editor dos juristas. São Paulo: Revista dos Tribunais, 1995. p. 173-182.

LACERDA, Galeno. Processo e cultura. Revista de Direito Processual Civil, São Paulo, v. 2, n. 3, p.74-86, jan./ jun. 1961.

LIMA, Alcides de Mendonça. Processo civil no processo trabalhista. São Paulo: LTr, 1983. 
MACEDO JUNIOR, Ronaldo Porto. Ação civil pública, o direito social e os princípios. In: YARSHELL, Flávio Luiz; MORAIS, Maurício Zanoide de (Org.). Estudos em homenagem à professora Ada Pellegrini Grinover. São Paulo: DPJ, 2005. p. 290-299.

MARINONI, Luiz Guilherme Teoria geral do processo. 4. ed. São Paulo: Revista dos Tribunais, 2010.

MARINONI, Luiz Guilherme. Técnica processual e tutela dos direitos. São Paulo: Revista dos Tribunais, 2004.

MARTINS, Soveral. Processo e direito processual. Coimbra: Centelha, 1985. v. 1

MITIDIERO, Daniel Francisco. Colaboração no processo civil: pressupostos sociais, lógicos e éticos. São Paulo: Revista dos Tribunais, 2009.

MOREIRA, José Carlos Barbosa. Os novos rumos do processo civil brasileiro. In: MOREIRA, José Carlos Barbosa. Temas de direito processual: sexta serie. São Paulo: Saraiva, 1997. p. 193-208.

NASCIMENTO, Amauri Mascaro do. Curso de direito processual do trabalho. 17. ed. São Paulo: Saraiva, 1997.

NERY JR., Nelson. Princípios do processo civil na Constituição. São Paulo: Revista dos Tribunais, 1992.

NOGUEIRA, Carlos Alberto. Las transformaciones del proceso civil y la política procesal. In: BERIZONCE, Roberto O. et al. La justicia entre dos épocas. Buenos Aires: LEP, 1983. p. 15-56.

OLIVEIRA, Carlos Alberto Álvaro. Procedimento e ideologia no direito brasileiro atual. In: TUBENCHLAK, James; BUSTAMENTE, Ricardo (Coord). Livro de estudos jurídicos. Rio de Janeiro: Instituto de Estudos Jurídicos, 1992. v. 4.

OVALLE FAVELA, José. Teoría general del proceso. 6. ed. Ciudad del Mexico: Oxford, 2005.

PAULA, Adriano Perácio de. Direito processual do consumidor. Belo Horizonte: Del Rey, 2002.

Rocha, José de Albuquerque. Teoria geral do processo. 7. ed. São Paulo: Atlas, 2003.

SANTOS AZUELA, Héctor. La teoria general del proceso en el sistema del Derecho Procesal Social. Boletin Mexicano de Derecho Comparado, Mexico (DF), v. 34, n. 101, p. 567-588, mayo/ago. 2001. Disponible en: $<$ http://biblio.juridicas.unam.mx/revista/pdf/DerechoComparado/101/art/art6.pdf>. Acceso en: 26 abr. 2002

SAVARIS, José Antônio. Direito processual previdenciário. 4. ed. Curitiba: Juruá, 2012.

SILVA, Moacir Motta da; VERONESE, Josiane Rose Petry. A tutela jurisdicional dos direitos da criança e do adolescente. São Paulo: LTr, 1998.

SILVA, Ovídio A. Baptista da. Juizado de pequenas causas. Porto Alegre: Letras Jurídicas, 1985.

Silva, Ovídio Araújo Baptista da; GOMES, Fábio. Teoria geral do processo civil. 2. ed. São Paulo: Revista dos Tribunais, 2000.

SUNDFELD, Carlos Ari. O direito processual e o direito administrativo. In: SUNDFELD, Carlos Ari; BUENO, Cássio Scarpinella. Direito processual público: a fazenda pública em juízo. São Paulo: Malheiros, 2000. p. $15-30$.

TAYLOR, Charles. Multiculturalismo: examinando a política de reconhecimento. Trad. Marta Machado.Lisboa: Instituto Piaget, 1998.

TESSLER, Luciane Gonçalves. Tutelas jurisdicionais do meio ambiente: tutela inibitória, tutela de remoção, tutela de ressarcimento na forma específica. São Paulo: Revista dos Tribunais, 2004.

TUCCI, José Rogério Cruz. e. Tempo e processo: uma análise empírica das repercussões do tempo na fenomenologia processual (civil e penal). São Paulo: Revista dos Tribunais, 1997.

TUCCI, Rogério Lauria. Teoria do direito processual penal. São Paulo: Revista dos Tribunais, 2002. 
VIGLIAR, José Marcelo Menezes. Tutela jurisdicional coletiva. 3. ed. São Paulo: Atlas, 2001.

WAMBIER, Teresa Arruda Alvim. Controle das decisões judiciais por meio de recursos de estrito direito e de ação rescisória. São Paulo: Revista dos Tribunais, 2001.

YARSHELL, Flávio Luiz. Tutela jurisdicional. São Paulo: Atlas, 1999. 
Para publicar na revista Brasileira de Políticas Públicas, acesse o endereço eletrônico www.rbpp.uniceub.br

Observe as normas de publicação, para facilitar e agilizar o trabalho de edição. 